\title{
Failure Mechanism and Optimization of Arch-Bolt Composite Support for Underground Mining Tunnel
}

\author{
Yuchun Mei $\mathbb{D},{ }^{1}$ Weiteng Li $\mathbb{D},{ }^{1}$ Ning Yang $\mathbb{D},{ }^{1,2,3}$ Gang Wang $\mathbb{D},{ }^{1}$ Tingchun $\operatorname{Li}\left(\mathbb{D},{ }^{1}\right.$ \\ and Linlin Sun $\mathbb{D D}^{1}$ \\ ${ }^{1}$ Shandong Provincial Key Laboratory of Civil Engineering Disaster Prevention, Shandong University of Science and Technology, \\ Qingdao 266590, China \\ ${ }^{2}$ Jiangsu Vocational Institute of Architectural Technology, Xuzhou 221116, China \\ ${ }^{3}$ JiangSu Collaborative Innovation Center for Building Energy Saving and Construction Technology, Xuzhou 221116, China
}

Correspondence should be addressed to Weiteng Li; lwteng2007@163.com

Received 17 September 2019; Revised 30 November 2019; Accepted 5 December 2019; Published 17 January 2020

Academic Editor: Farhad Aslani

Copyright @ 2020 Yuchun Mei et al. This is an open access article distributed under the Creative Commons Attribution License, which permits unrestricted use, distribution, and reproduction in any medium, provided the original work is properly cited.

\begin{abstract}
Numerical simulation tests were performed on the arch-bolt combined supported mining tunnel through an improved numerical simulation approach. The typical soft rock roadway was took as the background, and the influencing factors such as ground stress level, lateral pressure coefficient, and support type and parameters were considered. The failure mechanism of a semicircular roadway with two straight walls was analyzed; results showed that the arch legs' inward bending deformation and the arch-rock separation are the breakthrough of the global failure of the supporting system, and rock bolts breakage promoted the failure process. The effects of different controlling measures were analyzed including enlarging the bolt diameter, replacing the conventional bolts with energy-absorbing bolts, and setting arch locking bolts on the arch legs. The field test of the concrete-filled steel tube (CFST) arch-bolt composite support scheme was carried out in a high-stress soft rock roadway, and the results indicate the reliability of the main conclusions.
\end{abstract}

\section{Introduction}

In recent years, the mining depth is getting deeper and deeper, no matter in metal mines or in coal mines. There are about 60 $1 \mathrm{~km}$-deep coal mines in China now $[1,2]$. With the adjustment of China's coal mining strategy, more and more coal mines are constructed in extremely soft rock strata (e.g., in Neimeng and Ningxia in west China), swelling soft rock strata (e.g., in the Longkou mining area in east China), water-rich strata, and other complex conditions. The roadway support is generally difficult in the above-mentioned situation, the commonly used rock bolt-shotcrete support is too weak to maintain the roadway stability. Therefore, arch-bolt-shotcrete combined support became a common used reinforced support style for the above conditions. The supporting arches mainly include the traditional U-shaped steel arch [3-5] and the new developed concrete-filled steel tubular arch [6-9]. But sometimes this kind of high-strength support still cannot prevent the roadway deformation and failure.
In a roadway supported with the arch-bolt composite support system, the arches with higher stiffness can hardly couple with the other components, which are relatively flexible, such as rock bolts, anchor cables, and the shotcrete layer. In practice, the supporting members are usually broken down one by one, and the whole supporting system fails step by step. Therefore, the key problem in an arch-bolt composite-supported roadway is how to achieve coordination among the various components in the arch-bolt composite support system and achieve coupling between the mechanical behaviors of surrounding rocks and supports. In fact, a lot of research has revealed the interaction mechanism between bolts and rocks in a roadway [10-13]. Some work has also discussed the failure mechanism of roadways with supporting arches such as steel set with I- or U-shaped cross sections $[5,14,15]$. Little effort has been spent on the combined support action supplied by bolts and arches on the surrounding rocks or interactions among the above three objects. The basic model of rock-support interaction can be 
established theoretically, and the fundamental interaction mechanism can be revealed, but in the theoretical method, simplifications cannot be avoided, such as simplifying the roadway to a circular shape and equalizing the supporting action of the arch, shotcrete, and bolt with linear support forces with certain stiffness $[3,16]$. Therefore, the limitations of using the theoretical method to solve this complex problem are obvious. Model testing is an effective research tool for the above problem, but the cost of testing is too high to be used widely. Thus, the numerical simulation method, which has been greatly improved, is widely used for researching the problem. In the reported numerical simulation research, emphasis was placed on the description of the characteristics of the surrounding rocks [17-21], but considering the mechanical behaviors of supporting members is rare.

To solve the above defects, Li et al. [22] proposed an improved numerical simulation approach through additional development of FLAC ${ }^{3 D}$. The approach consists of four parts: a yieldable supporting arch module, a separable arch-rock interaction module, a breakable anchor bolt module, and a practicable surrounding rock module. The yield criterion of the supporting arch was proposed and embedded in the modified beam element via the FISH language programming. A separation criterion is proposed for the arch-rock interaction link, and the separable archrock interaction module is realized through modifying the normal-yield attachments of the built-in arch-rock links. A tensile breakage failure criterion is proposed for the anchor bolt using the ultimate elongation ratio of the whole anchorfree part as the criterion. Analysis showed that the improved numerical simulation approach is much more reliable for large deformation roadway behavior with arch-bolt composite support, especially concerning the bearing and failure behaviors of the supporting arch and anchor bolt. In this article, systematic simulation tests will be performed using this simulation approach, and the failure mechanism of the arch-bolt composite support in the mining roadways will be studied, and the optimized control measures will be proposed.

\section{Comparative Analysis on Failure Mechanism}

2.1. Engineering Background: An Extremely Soft Rock Roadway. Liangjia Coal Mine is located in the eastern coast of China, with an output of $3000000 t$ per year, and some mining areas are under the sea. The gateway tunnels of the 4606 working face is the object of this article. The profile of the roadway consists of two straight walls and one semicircular arch. The height of the wall is $1.6 \mathrm{~m}$, and the radius of the arch is $2.2 \mathrm{~m}$. The roadway is located in the 4th coal seam, the top layers are coal and mudstone in turn, and the bottom layer is oil shale (Figure 1(a)). Because the rock mass is extremely soft and fragmented, the stability of roadway surrounding rock is very poor. The vertical in situ stress is $10 \mathrm{MPa}$, the horizontal major principal stress is $14.5 \mathrm{MPa}$, and the direction is basically parallel to the roadway axis; the horizontal minor principal stress is $10 \mathrm{MPa}$. The roadway is supported by U-steel arch + bolt + shotcrete, with a row of 16 bolts every $0.8 \mathrm{~m}, 2.25 \mathrm{~m}$ in length, $18 \mathrm{~mm}$ in diameter, $0.8 \mathrm{~m}$ in anchorage length, and $20 \mathrm{kN}$ in preforce. The grade of shotcrete is $\mathrm{C} 20$, and the thickness is $0.12 \mathrm{~m}$, the spacing of U36-steel $(36 \mathrm{~kg} / \mathrm{m})$ arch is $0.8 \mathrm{~m}$. Displacement of the roadway floor reached $900 \mathrm{~mm}$, and the value on the side wall reached almost $500 \mathrm{~mm}$ at $120 \mathrm{~d}$ after excavation, and the rheological characteristics are obvious. Failures occurred on the legs of the supporting arches, as shown in Figure 1(b), and then the arch lost stability as a whole, as shown in Figure 1(c). Subsequently, the roadway surrounding rock deformation continued, and some of the rock bolts broke.

\subsection{Test Schemes}

2.2.1. Designation of the Comparing Schemes. Numerical simulation whose parameters are basically consistent with the above engineering case has been carried out, and the reliability of the numerical simulation method and parameters used were verified [22]. The test schemes shown in Table 1 are designed based on the above premise. The vertical ground stress values change in Schemes 1-5, and the lateral ground stress coefficient $\lambda$ is set as 1.0; however, in Schemes $6-10$, the lateral ground stress coefficient values change, and the vertical ground stress is set as $10 \mathrm{MPa}$. Here, the lateral ground stress indicates the horizontal ground stress that is vertical to the axial direction of the roadway model. While the horizontal ground stress that is parallel to the axial direction of the roadway model is set at the same value as the vertical ground stress, all of the schemes have the same supporting parameters as shown in Table 1. Because the U-steel arch is too easy to fail, the CFST support with higher strength is selected as the supporting arch type in the schemes, for more convenient comparative analysis. A supporting arch is generally composed of four concretefilled steel tubular components and three casing tubes as shown in Table 1 . The supporting ability is much higher than the conventional U-steel-supporting arch and developed rapidly in recent years $[9,23]$.

2.2.2. Modeling of Ground and Roadway. The total size of the model is width $\times$ height $\times$ thickness $=40 \mathrm{~m} \times 40 \mathrm{~m} \times$ $0.8 \mathrm{~m}$, and the shape and sizes of the roadway are the same to the real one, as shown in Figure 2(a). The displacement of the bottom surface of the model are constrained in all directions. There is no displacement constrain set to the top surface, but the equivalent ground stress corresponding to the up strata is applied on it. The displacement in the normal direction of the other 4 surfaces are constrained. The mechanical model and parameters of the surrounding rock elements are set according to Table 2, and the ground stress is initialed according to Table 1 .

\subsubsection{Modeling of the Support Members}

(1) Shotcrete layer: the shotcrete is modeled with solid elements with a thickness of $0.12 \mathrm{~m}$, as shown in Figure 2(b). The Mohr-Coulomb model is chosen, elastic modulus is $5000 \mathrm{MPa}$, passion's ratio is 0.2 , 


\begin{tabular}{|c|c|c|c|}
\hline & Lithology & Cylindrical & $\begin{array}{l}\text { Thickness }(\mathrm{m}) \\
\text { Buried depth }(\mathrm{m})\end{array}$ \\
\hline $\begin{array}{c}\text { Basic } \\
\text { roof }\end{array}$ & $\begin{array}{l}\text { Mudstone } \\
\text { fine } \\
\text { sandstone }\end{array}$ & 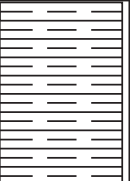 & $\begin{array}{c}59.36 \\
818.47\end{array}$ \\
\hline \multirow[b]{2}{*}{$\begin{array}{l}\text { Direct } \\
\text { roof }\end{array}$} & $\begin{array}{c}\text { Coal layer } \\
4 \#\end{array}$ & & $\begin{array}{l}0.908 \\
19.37 \\
\end{array}$ \\
\hline & $\begin{array}{l}\text { Mudstone } \\
\text { with coal }\end{array}$ & 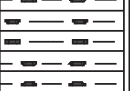 & $\begin{array}{c}15.27 \\
834.64\end{array}$ \\
\hline $\begin{array}{l}\begin{array}{c}\text { Coal } \\
\text { seam }\end{array} \\
\end{array}$ & $\begin{array}{c}\text { Coal layer } \\
4 \#\end{array}$ & & $\begin{array}{c}13.72 \\
848.36 \\
\end{array}$ \\
\hline \multirow{2}{*}{$\begin{array}{l}\text { Direct } \\
\text { floor }\end{array}$} & Mudstone & 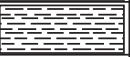 & $\begin{array}{c}0.65 \\
849.01 \\
\end{array}$ \\
\hline & Oil 4 & $\Leftrightarrow 2$ & $\begin{array}{c}2.32 \\
851.32\end{array}$ \\
\hline
\end{tabular}

(a)

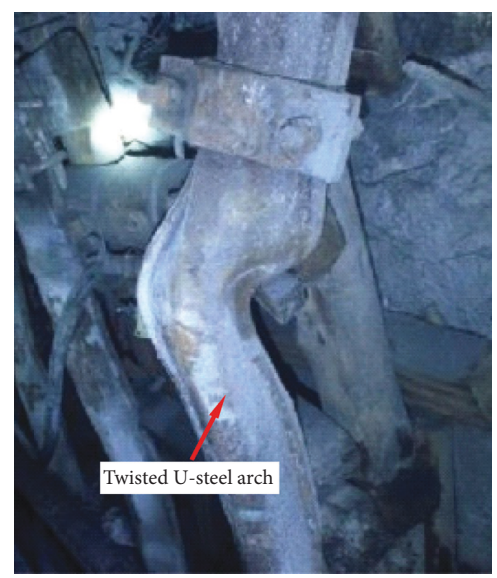

(b)

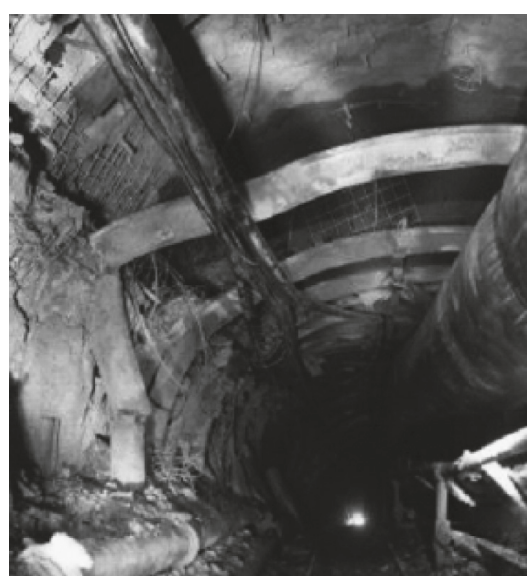

(c)

FIGURE 1: Deformation and failure situation of the 4606 roadway. (a) Stratum profile. (b) Twisted U-steel arch leg. (c) Global deformation of the roadway and supporting arch.

TABle 1: Test schemes.

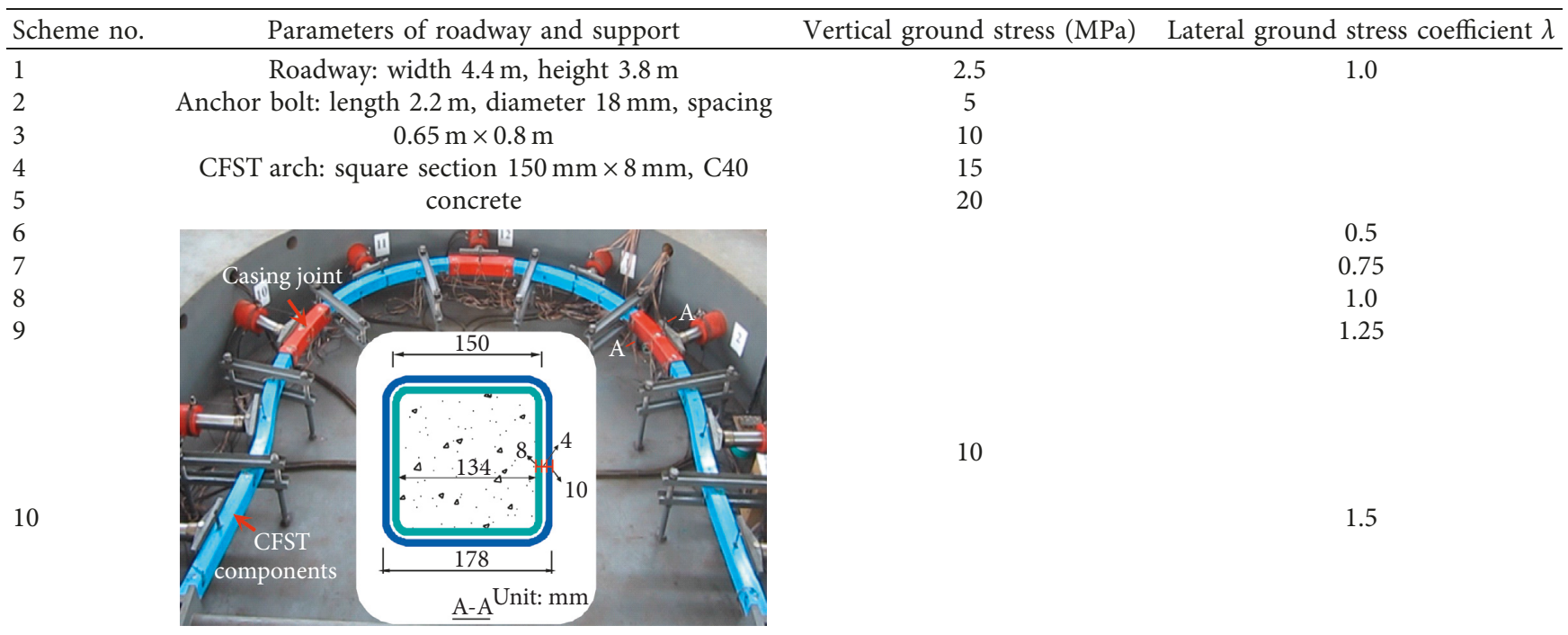

tension strength is $1.0 \mathrm{MPa}$, cohesion is $1.0 \mathrm{MPa}$, and inner friction angle is $30^{\circ}$.

(2) Rock bolt: rock bolts are modeled with cable elements on the middle section of the model, numbered as 1-16 as shown in Figure 2(b). Cross-sectional area of the bolt is $2.54 \mathrm{~cm}^{2}$, elastic modulus is $200 \mathrm{GPa}$, yield force is $171.8 \mathrm{kN}$, and preload is $20 \mathrm{kN}$. Each bolt consists of $220.1 \mathrm{~m}$-length cable elements connected end to end. The element near the profile of the roadway is the outside anchorage segment, and then, the 13 inner elements form the anchor-free segment of the bolt, and the innermost 8 elements form the inner anchorage segment, as shown by the $3 \#$ bolt in Figure 2(c). The anchorage parameters of the outer anchorage segment are bulk modulus $10000 \mathrm{MPa}$, cohesion $10000 \mathrm{MPa}$, and inner friction angle $25^{\circ}$; the anchorage parameters of the inner anchorage segment are bulk modulus $20 \mathrm{MPa}$, cohesion $20 \mathrm{MPa}$, and inner friction angle $45^{\circ}$; the anchorage parameters of the anchor-free segment are bulk modulus $0 \mathrm{MPa}$, cohesion $0 \mathrm{MPa}$, inner friction angle $0^{\circ}$, and the links between the cable element of anchor-free segment and rock zones are all deleted, as shown in Figure 2(c). According to the practice situation of anchor bolts in roadways [24], the breakage elongation ratio of the anchor-free segment is set as $10 \%$ [22].

(3) Modeling of the arches: the supporting arch is a CFST cross-sectional arch, settled on the same cross section with the rock bolts spaced at $0.8 \mathrm{~m}$. The rock bolt and arch are independent of each other according to the actual situation, although they seem to be in the same section and have intersections as shown in Figure 2(b). An arch consists of 4 conventional CFST segments and 3 casing joints with 

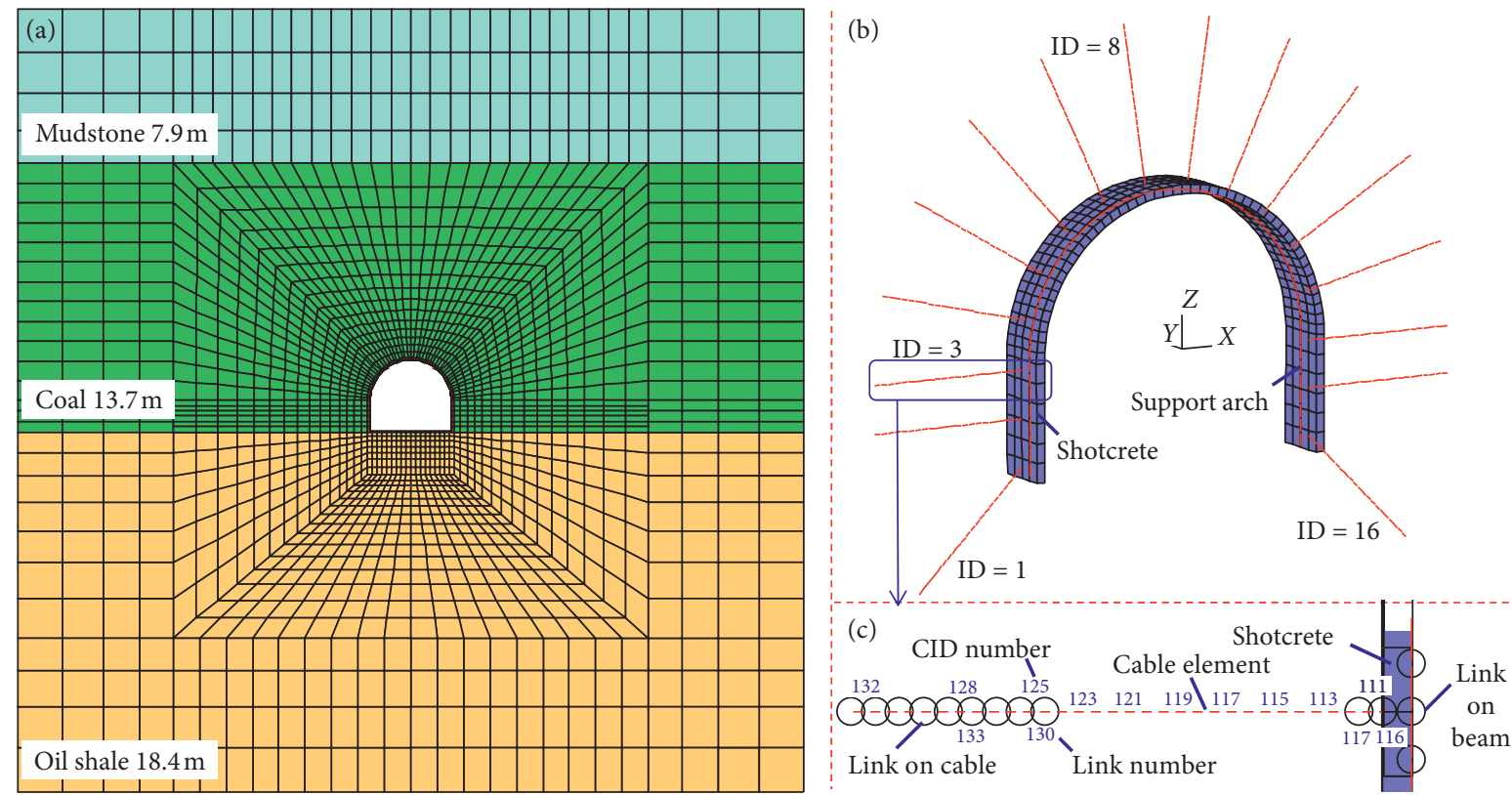

Figure 2: Numerical model. (a) Roadway and surrounding rocks. (b) Shotcrete layer, supporting arch, and rock bolts. (c) Rock bolts model details.

TABLE 2: Mechanical parameters of surrounding rock model.

\begin{tabular}{|c|c|c|c|c|c|c|c|c|c|c|}
\hline $\begin{array}{l}\text { Ground } \\
\text { layers }\end{array}$ & $\begin{array}{c}\text { Bulk } \\
\text { modulus } \\
B(\mathrm{MPa})\end{array}$ & $\begin{array}{c}\text { Poisson's } \\
\text { ratio } \mu\end{array}$ & $\begin{array}{l}\text { Tension } \\
\text { strength } \\
\sigma_{\mathrm{t}}(\mathrm{MPa})\end{array}$ & $\begin{array}{l}\text { Cohesion } \\
C(\mathrm{MPa})\end{array}$ & $\begin{array}{c}\text { Inner } \\
\text { friction } \\
\text { angle } \psi \\
\left(^{\circ}\right)\end{array}$ & $\begin{array}{l}\text { Density } \\
\left(\mathrm{kg} / \mathrm{m}^{3}\right)\end{array}$ & $\begin{array}{l}\text { Elastic shear } \\
\text { modulus } G_{\mathrm{M}} \\
\qquad(\mathrm{GPa})\end{array}$ & $\begin{array}{l}\text { Kelvin shear } \\
\text { modulus } G_{\mathrm{K}} \\
\quad(\mathrm{GPa})\end{array}$ & $\begin{array}{c}\text { Maxwell } \\
\text { dynamic } \\
\text { viscosity } \eta_{\mathrm{M}} \\
(\mathrm{GPa} \cdot \mathrm{s})\end{array}$ & $\begin{array}{c}\text { Kelvin } \\
\text { viscosity } \\
\eta_{\mathrm{K}}(\mathrm{GPa} \cdot \mathrm{s})\end{array}$ \\
\hline Mudstone & 500 & 0.3 & 0.15 & 0.5 & 27 & 2200 & 1.0 & 5.23 & $1.1 \times 10^{8}$ & $1.73 \times 10^{6}$ \\
\hline Coal & 400 & 0.3 & 0.1 & 0.4 & 25 & 2200 & 1.0 & 5.23 & $1.1 \times 10^{8}$ & $1.73 \times 10^{6}$ \\
\hline Oil shale & 600 & 0.3 & 0.15 & 0.6 & 27 & 2200 & 1.0 & 5.23 & $1.1 \times 10^{8}$ & $1.73 \times 10^{6}$ \\
\hline
\end{tabular}

length $600 \mathrm{~mm}$ placed on the crown and the two shoulders $\left(45^{\circ}\right.$ below the arch crown point) of the arch. The geometric and the cross-sectional parameters are shown in Table 3, which is determined based on the field practice. The supporting arch was composed of 52 beam elements along the roadway profile. The compression-bending yield functions used in the supporting arch model are also shown in Table 3 , where $m$ equals to bending moment $M$ divided by $M_{\mathrm{u}}$, and $n$ equals to axial force $N$ divided by $N_{\mathrm{u}}$, and $M_{\mathrm{u}}$ is the bearing capacity of the pure bending CFST beam, and $N_{\mathrm{u}}$ is the bearing capacity of the compression CFST column; $M$ and $N$ are the bending moment and axial force of one section, respectively. $k_{N}^{\prime}$ and $k_{M}^{\prime}$ are valued as $k_{\mathrm{N}} / 1000$ and $k_{\mathrm{M}} / 1000$, respectively, where $k_{\mathrm{M}}$ and $k_{M}^{\prime}$ are the flexural rigidities before and after the bending yielding action, and $k_{\mathrm{N}}$ and $k_{N}^{\prime}$ are the axial stiffness before and after the compressive yielding action. The parameters of the separable links are $F_{\mathrm{t}}=0.2 \mathrm{kN}$, $F_{\mathrm{c}}=-1 \times 10^{17} \mathrm{kN}$, gap $=$ on, and $k=5 \times 10^{6}$, where $F_{\mathrm{c}}$ is the compressive yield strength (force units), and $F_{\mathrm{t}}$ is the tensile yield strength (force units), $k$ is the stiffness per unit area, gap $=$ on means a gap may form in both the positive and negative directions when yielding occurs in these directions. For more detailed information on modeling parameters, refer to Li et al. [22].

\subsection{Results and Analysis}

2.3.1. Typical Failure Process. Scheme 4 (ground stress $15 \mathrm{MPa}$ ) is the most typical one, and it is taken as an example here for the analysis of the gradual failure process of the roadway support.

Figure 3(a) shows the roadway surface displacement developing curves. Figures 3(b)-3(d) show the developing curves of the axial forces, bending moments, and supporting forces of typical sections on the supporting arch. Figure 3(e) shows the axial forces developing curves of typical anchor bolts, and Figures 3(f)-3(i) present diagrams of the typical surrounding rock plastic zone and inner force of support structures.

The displacement values grow with time in a linear pattern before the $10^{\text {th }}$ day as shown in Figure 3(a). On the $5^{\text {th }}$ day, the boundary of the plastic zone almost reached the inner end of the rock bolts (Figure 3(f)); the displacements 
TABLE 3: Geometry and mechanical parameters of the supporting arches.

\begin{tabular}{|c|c|c|c|c|}
\hline Cross-section type & $\begin{array}{l}\text { Cross section } \\
\text { area }\left(\mathrm{m}^{2}\right)\end{array}$ & $\begin{array}{l}\text { Equivalent inertial } \\
\text { moment }\left(\mathrm{mm}^{4}\right)\end{array}$ & $\begin{array}{l}\text { Equivalent elastic } \\
\text { module }(\mathrm{Pa})\end{array}$ & $\begin{array}{l}\text { Compression-bending failure criteria }(m-n \\
\text { formulas) }\end{array}$ \\
\hline $\begin{array}{l}\text { CFST square cross section } \\
150 \mathrm{~mm} \times 8 \mathrm{~mm} \text {, concrete } \\
\text { grade } \mathrm{C} 40\end{array}$ & 0.0225 & 4218.75 & $0.05 \times 10^{11}$ & $\left\{\begin{array}{c}m=-0.717 n^{2}-0.062 n+1 \quad n \leq 0.3017 \\
m=-0.51 n^{2}-0.685 n+1.1951 \quad n>0.3017 \\
N_{\mathrm{u}}=2526 \mathrm{kN}, M_{\mathrm{u}}=101.7 \mathrm{kN} \cdot \mathrm{m}\end{array}\right.$ \\
\hline U36 & 0.004569 & $9.29 \times 10^{6}$ & $2.06 \times 10^{11}$ & $\begin{array}{cl}m=-0.717 n^{2}-0.062 n+1 & n \leq 0.3017 \\
m=-0.51 n^{2}-0.685 n+1.1951 & n>0.3017 \\
& N_{\mathrm{u}}=1457.6 \mathrm{kN}, M_{\mathrm{u}}=48.3 \mathrm{kN} \cdot \mathrm{m}\end{array}$ \\
\hline
\end{tabular}

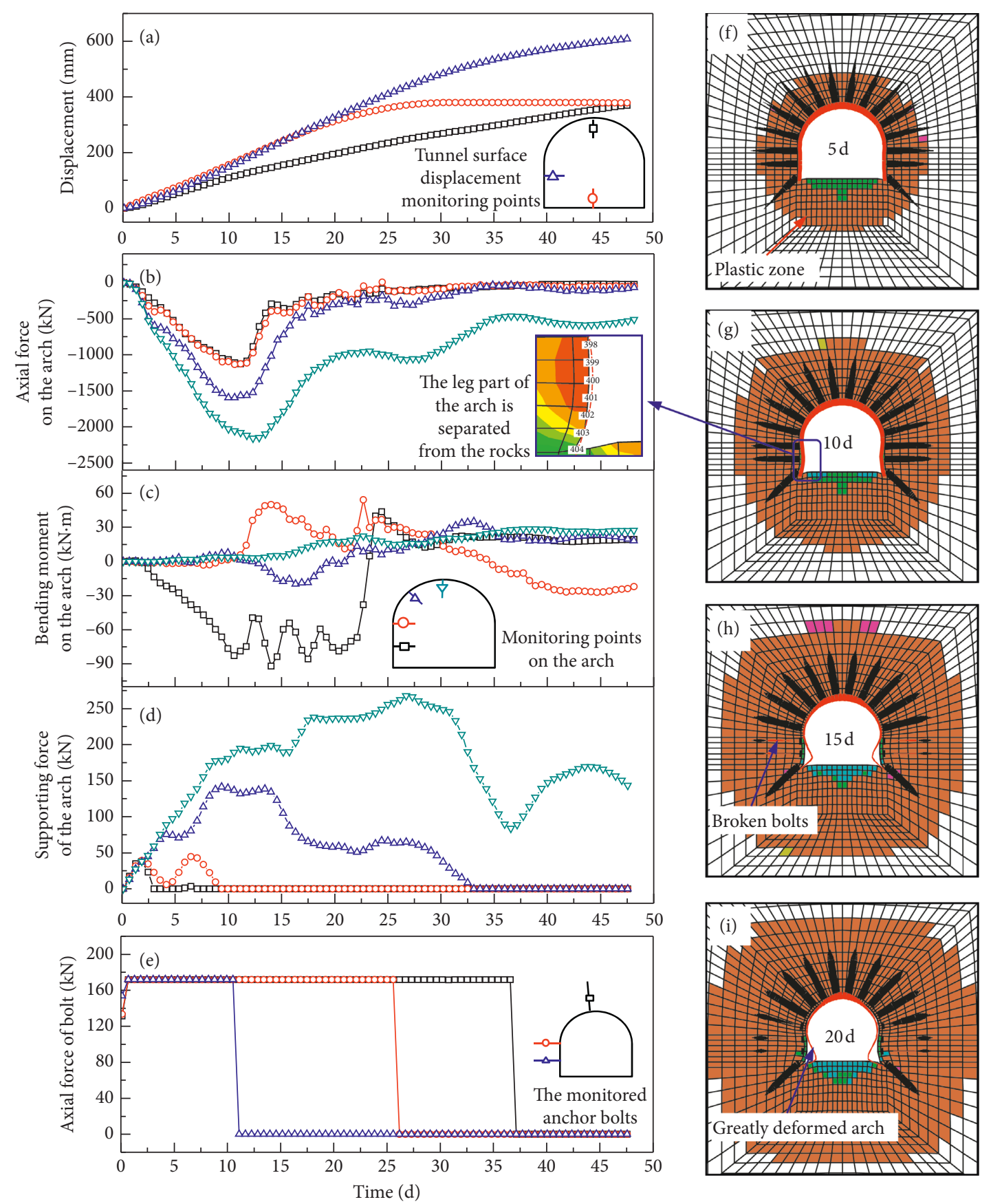

Figure 3: Result diagrams of Scheme 4 (ground stress $15 \mathrm{MPa}$ ). (a) (e): Development curves of roadway displacement, arch axial force, arch bending moment, arch supporting force, and rock bolt axial force, respectively; (f) (i): diagrams of plastic zone and supporting structure inner force at the $5^{\text {th }}$ day, $10^{\text {th }}$ day, $15^{\text {th }}$ day, and the $20^{\text {th }}$ day, respectively. (Supporting arches and rock bolts are presented as the axial force diagrams; the thicker the line, the greater the axial force. When the line thickness of the bolt axial force diagrams is 0 , it means the bolts are broken.) 
of the side wall, roof, and floor are similar; and the rock bolts are working with full loading. On the $10^{\text {th }}$ day, the plastic zone boundary exceeded the rock bolts by about $0.7 \mathrm{~m}$ (Figure $3(\mathrm{~g})$ ), and the deformations of the roadway became larger. In the above process, the axial forces and bending moments of the arch show linear growing pattern (Figures 3(b) and 3(c)). The axial force diagrams in Figures 3(f)-3(i) show that the axial force is highest on the arch crown, and the axial force decreases when the cross section drops, whereas the ultimate bending moment appears on the arch leg, and the value is apparently larger than that on the other sections. The deformation of the arch developed when the inner forces changed; the arch legs bent inward the excavation space because of the surrounding rock pressure. The bending deformation was easy to see at the $10^{\text {th }}$ day, and the arch leg started to be separated from the rocks (Figure 3(g)).

Because of the above arch-rock separation, the supporting forces of the arch legs reduced to 0 after fluctuation as shown in Figure 3(d). The arch legs totally lost their support function on the rocks on the $10^{\text {th }}$ day, which accelerated the deformation and failure process of the side wall rocks and stretched the bolts on the side more significantly than the bolts in the other positions. The bolt located on the half height of the wall broke first on the $11^{\text {th }}$ day (Figures 3(e) and 3(h)). Also, on the $10^{\text {th }}$ day, the beam element on the half height of the leg $(\mathrm{CID}=357$, the CID refers to the serial number of the beam element) failed because the compression-bending yield criterion was satisfied. Then, the beam CIDs 401, 358, 402, 356, and 400 (all located on the half height range of the arch legs) failed one by one. The arch legs' bending failure started the global failure of the supporting arch because the bending deformation of the legs developed faster, and the supporting arch began to fail globally.

The failure of the legs leaded the axial forces and supporting forces of the arch decreased rapidly after the $10^{\text {th }}$ day. The values of the axial forces and supporting forces on the monitoring beam elements decreased to 0 after the 33th day (Figure 3(d)), which means the arch lost its stability and supporting function totally. After that, although there was a rate reduction, the deforming rate of the surrounding rocks was still high. The bolts were almost all broken on the $37^{\text {th }}$ day, the arch-bolt composite support system failed globally, and the roadway was still deforming on the $50^{\text {th }}$ day.

The above failure process can be summarized as follows: (a) First, the shape of the roadway (semicircular with two straight walls) dictated that the side walls significantly deformed inwardly at the beginning. This action made the bending moments in the arch legs increase significantly, and the inner forces reached the compression-bending criterion quickly. This led to fast deformation of the arch legs and the global instability of the arch. (b) Second, the shape and the mechanical environment of the supporting arch meant that the deformation rate of the arch legs was greater than the rate of the side wall rocks, which caused the arch-rock separation. This means that the rocks on the side wall of the roadway lost support at an early stage, which caused further serious failure. (c) Third, the rock bolts breakage during the above evolution aggravated the failure of the roadway support. There are two crucial points in the failure process: the compression-bending failure of the arch legs and the separation between the arch legs and the rocks.

The above analysis shows the following support failure characteristics of a semicircular soft rock roadway with two straight walls, supported with an arch-bolt composite support system. (a) The rheological features of the surrounding rock deformation are obvious, and the duration time is long. (b) The serious deformations of the arch legs and the side walls are the critical points that led to the final deformation and failure of the whole roadway. (c) From the point of view of mechanics, the semicircular shape with two straight legs is adverse for stable control of the surrounding rock. The arch leg parts are prone to bending failure, and the macrocharacteristics of the global arch structure means that once the compression-bending failure happens on the arch legs, the support on the side wall rocks will be completely lost. (d) The bolts may be broken easily in this kind of roadway.

\subsubsection{Influences of Ground Stress (Comparing Analysis on} Schemes 1-5). Some results of Scheme 1-5 were listed in Table 4, including surrounding rock displacements, plastic volumes, support structure forces, and working status. Figure 4 shows the developing curves of each monitored index of Scheme 2 (ground stress $5 \mathrm{MPa}$ ) and Scheme 3 (ground stress $10 \mathrm{MPa}$ ). Figure 5 shows the plastic zones of the surrounding rocks and support structure inner force diagrams of Schemes 1-4 with different ground stresses. follows.

The deformation and failure process are analyzed as

(1) In Scheme 2 (ground stress $5 \mathrm{MPa}$ ), the deformations are smaller, the roadway is basically stable at the $50^{\text {th }}$ day (Figure 2(a)), and the range of the plastic zone does not exceed the rock bolt inner end (Figure 5(b)). The 6 bolts on the side walls reached the ultimate axial force but did not break (Figure 5(b)). The arch inner forces were much lower than the extreme value, and the arch supporting forces are stable and function normally, and there is still a margin remaining. The roadway deformations of Scheme 1 (ground stress 2.5 MPa) were much smaller than those in Scheme 2, the plastic zone boundary did not exceed the rock bolt inner end (Figure 5(a)), and the other laws shown in the results are similar to Scheme 2.

(2) In Scheme 3 (ground stress $10 \mathrm{MPa}$ ), the deformations and failure are much more serious, compared with Schemes 1 and 2. The roadway roof and side walls were still deforming at the $50^{\text {th }}$ day (Figure $4 \mathrm{~F}$ ), the plastic zone boundary exceed the bolt inner end by about $1.5 \mathrm{~m}$ (Figure 5(c)), and all rock bolts were fully loaded. The arch legs were bent inward, which gradually reduced the arch supporting force and even reduced the force to 0 on the arch legs, resulting in a resurgence in the rise of the roadway deformation curves, which were almost stable previously. 
Table 4: Main results of schemes 1-5 (time $50 \mathrm{~d}$ ).

\begin{tabular}{|c|c|c|c|c|c|c|c|c|c|}
\hline \multirow{2}{*}{$\begin{array}{l}\text { Scheme } \\
\text { no. }\end{array}$} & \multicolumn{3}{|c|}{ Displacement } & \multirow{2}{*}{$\begin{array}{c}\text { Plastic } \\
\text { volume }\left(\mathrm{m}^{3}\right)\end{array}$} & \multicolumn{3}{|c|}{ Maximum forces } & \multicolumn{2}{|c|}{$\begin{array}{l}\text { Working status of support } \\
\text { members }\end{array}$} \\
\hline & $\begin{array}{l}\text { Roof } \\
(\mathrm{mm})\end{array}$ & $\begin{array}{l}\text { Side wall } \\
(\mathrm{mm})\end{array}$ & $\begin{array}{l}\text { Floor } \\
(\mathrm{mm})\end{array}$ & & $\begin{array}{l}\text { Arch axial } \\
\text { force }(\mathrm{kN})\end{array}$ & $\begin{array}{l}\text { Arch bending } \\
\text { moment }(\mathrm{kN})\end{array}$ & $\begin{array}{l}\text { Bolt axial } \\
\text { force }(\mathrm{kN})\end{array}$ & Arch & Rock bolt \\
\hline 1 & 5.7 & 6.2 & 6.9 & 13.6 & 101.4 & 2.60 & 124.9 & Normal & Normal \\
\hline 2 & 22.7 & 29.4 & 28.5 & 31.2 & 417.2 & 9.92 & 171.8 & Normal & Normal \\
\hline 3 & 107.2 & 155.0 & 136.2 & 72.1 & 824.4 & 73.77 & 171.8 & Failed & Normal \\
\hline 4 & 370.0 & 608.1 & 379.2 & 136.4 & 521.3 & 53.11 & 171.8 & Failed & $\begin{array}{l}\text { Broken except the one } \\
\text { on the foots }\end{array}$ \\
\hline 5 & 339.1 & 494.5 & 482.4 & 110.4 & 308.0 & 97.01 & 171.8 & Failed & $\begin{array}{l}\text { Broken except the one } \\
\text { on the foots }\end{array}$ \\
\hline
\end{tabular}

(3) Scheme 4 (ground stress $15 \mathrm{MPa}$ ) was analyzed in Section 2.3.2 and is not repeated here. The failure of the surrounding rocks and support system in Scheme 5 (ground stress $20 \mathrm{MPa}$ ) is similar to that in Scheme 4 , but the deformations and failures are more serious. Because of the huge deformations, the calculation was interrupted at the $20.4^{\text {th }}$ day.

When comparing the roadway deformation curves shown in Figures 3(a), 4(a), and 4F, we see that the greater the ground stress, the worse the control effect of the supporting system and the longer the duration of the deformation. In fact, the rheological rock deformations were basically out of control when the ground stress reached $15 \mathrm{MPa}$. Comparison of the bolts' axial force curves show that the forces were close to the ultimate capacity when the ground stress was low, the bolts were all fully loaded when the ground stress reached $10 \mathrm{MPa}$, and the bolts gradually broke when ground stress reached $15 \mathrm{MPa}$. The supporting arch did not fail when the ground stress was low, but the arch failure happened when the ground stress reached $10 \mathrm{MPa}$, and it happened as soon as the $10^{\text {th }}$ day in the $15 \mathrm{MPa}$ scheme. The higher the ground stress, the earlier the failure of the arch, the faster the failure process, and the greater the reduction of supporting forces during the process. Figure 6 shows the variation curves of surrounding rock deformations and plastic volumes of Schemes 1-4. The deformation values and plastic zone volumes all increase with increases in ground stress, and the curves show exponential increases. When the ground stress is higher than $5 \mathrm{MPa}$, the side wall displacements become larger than the displacements of the roof and floor, and the differences are greater when the ground stress rises.

\subsubsection{Influences of Lateral Ground Stress Coefficients} (Comparing Analysis on Schemes 6-10). Some results of Scheme 6-10 were listed in Table 5. Figure 7 shows the evolution curves of each monitored index in Scheme 6 (lateral coefficient $\lambda=0.5)$ and Scheme $10(\lambda=1.5)$. Figure 8 shows the plastic zone of the surrounding rocks and support structure inner force diagrams of Schemes 6, 7, 9, and 10. follows.

The deformation and failing processes are analyzed as

In Scheme $6(\lambda=0.5)$, the bolts are fully loaded except the two on the roof, and the arch legs were bent slightly inward but had not failed, which is similar to that in Scheme $7(\lambda=0.75)$. In Scheme $8(\lambda=1.0$, the same scheme as Scheme 3), the arch legs yielded on the $15^{\text {th }}$ day and bent inward, and all bolts were fully loaded but not broken. In Scheme $9(\lambda=1.25)$, all bolts were fully loaded and the arch failed seriously. In Scheme 10 $(\lambda=1.5)$, there were two bolts broken on the side walls (Figures 7J and 8(d)) and the arch failed seriously.

When $\lambda$ is less than 1 , the width of the plastic zone is larger than the height, whereas the width is smaller than the height when $\lambda$ is greater than 1 . When $\lambda$ reaches 1.5 , the height of the plastic zone is about 2 times the width. Therefore, with an increase in $\lambda$, the shape of the plastic zone of the surrounding rock becomes taller and thinner.

When $\lambda$ is less than 1 , there is bending deformation on the arch legs, the inner force curves show that the arch legs did not yield, and the supporting force curves on the crown and shoulders did not show a reducing stage (Figures 7B-D). On the contrary, when $\lambda$ is larger than 1 , the arch yielded and failed and the inner force and supporting force curves show an obvious reducing stage (Figures 7G-I). Therefore, the ground stress lateral coefficient $\lambda$ obviously affects the inner forces and arch deformations, especially the inward bending deformation and yielding failure behaviors. The higher the value of $\lambda$, the higher the risk of losing the arch supporting forces.

As shown in Figure 9, the deformation values all increase with increases in $\lambda$, and the curves show an exponential increase. The curve slopes are not as significant as in Figure 6. Figure 9 also shows that the floor deformation is most obviously affected by $\lambda$, and the side wall is least affected. The volume of the plastic zone of the surrounding rock is larger when $\lambda$ is 0.5 , it is minimal when $\lambda$ is 0.75 , and then, it increases approximately linearly with increases in $\lambda$.

The comparison between Figures 9 and 6 shows that the influence of ground stress value on the roadway deformation is more significant than that of lateral ground stress coefficient. The response of the roadway side wall displacement is the strongest. When the ground stress increased from $2.5 \mathrm{MPa}$ to $15 \mathrm{MPa}$, the roadway side wall displacement increased by 76.8 times. When the lateral ground stress coefficient increased within the common value range, the response of the floor displacement is the strongest, and the floor heave increased by 2.5 times.

\section{Comparative Analysis on Control Measures}

3.1. Testing Schemes for Different Control Measures. To explore control measures for roadways supported with an arch- 

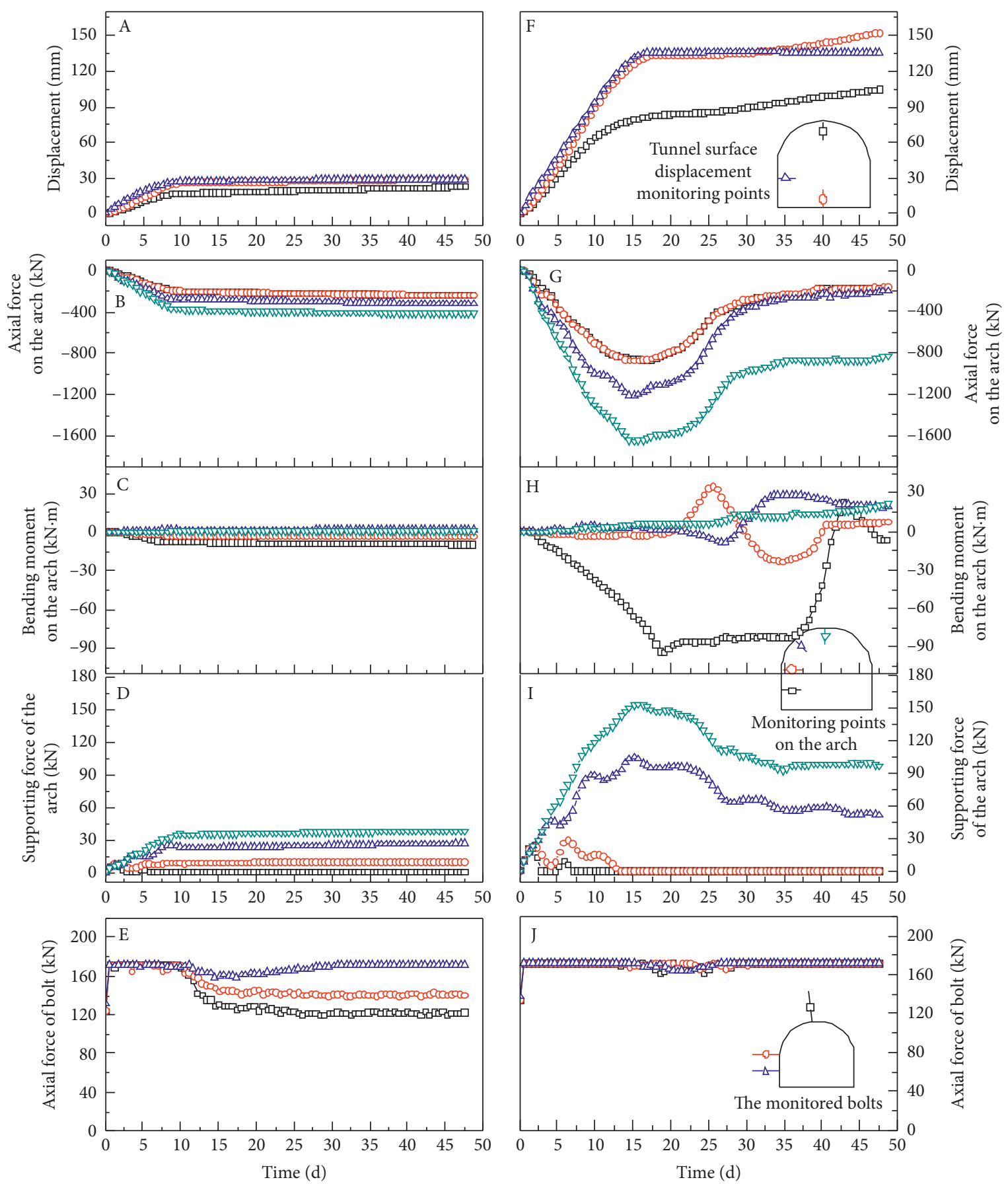

(a)

(b)

Figure 4: Evolution curves of Scheme 2 (ground stress $5 \mathrm{MPa}$ ) and Scheme 3 (ground stress $10 \mathrm{MPa})$. (A) (E): Evolution curves of roadway displacement, arch axial force, arch bending moment, arch supporting force, and rock bolt axial force of Scheme 2, respectively; (F) (J): Evolution curves of roadway displacement, arch axial force, arch bending moment, arch supporting force, and rock bolt axial force of Scheme 3, respectively. (a) Scheme $2(5 \mathrm{MPa})$. (b) Scheme $3(10 \mathrm{MPa})$.

bolt composite system that face problems similar to the above schemes, the test schemes listed in Table 6 were designed. Except the parameters listed in Table 6, the other parameters in the schemes are all the same as those in the schemes in Section 2.2. The breakage load of the $\Phi 22 \mathrm{~mm}$ bolts is $260 \mathrm{kN}$, and the broken elongation ratio is also $10 \%$. In Scheme 12, the energy- absorbing bolts (the broken elongation value is greater than the conventional one by $100 \mathrm{~mm}$ ) are used in the side walls, replacing the conventional rock bolts. The energy absorption principle is mainly absorbing energy through large extension of the anchor-free section of the anchor rod. In this scheme, the energy-absorbing bolt numerical model is actually realized by 

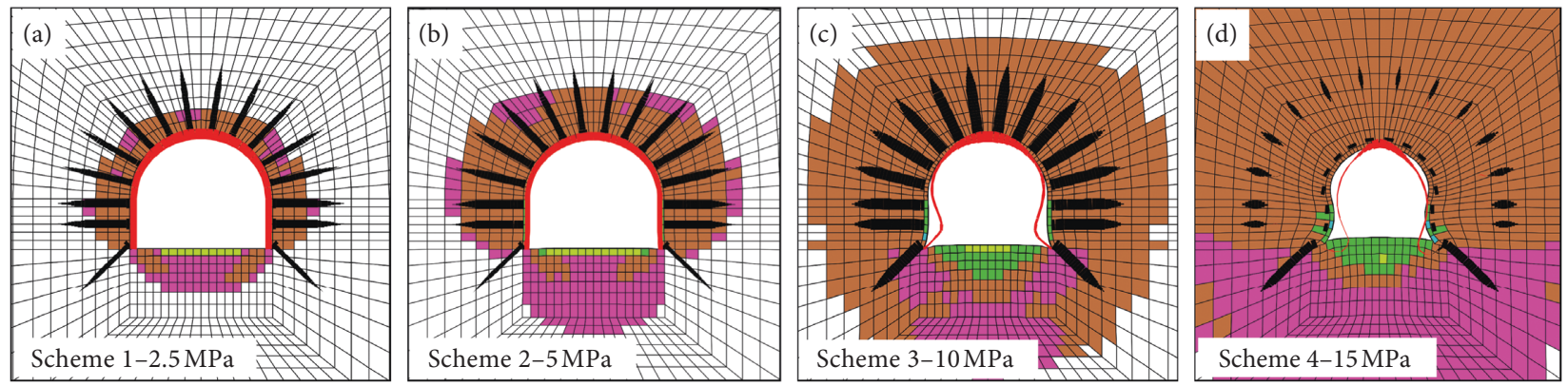

Figure 5: Surrounding rock plastic zones and supporting structure inner force diagrams of (a) Schemes 1, (b) Schemes 2, (c) Schemes 3, and (d) Schemes 4 at the 50th day.

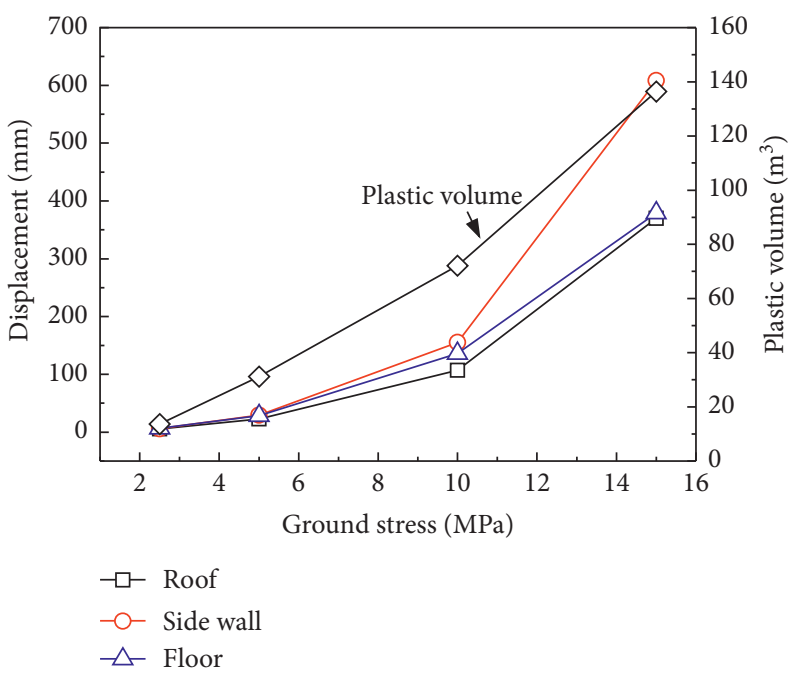

FIGURE 6: Variation curves of displacements and plastic zone volumes with lateral ground stress. (The results of Scheme 5 (ground stress $20 \mathrm{MPa}$ ) are not shown in the curves because of an interruption in the calculation.)

TABLE 5: Main results of Schemes 6-10 (time $50 \mathrm{~d}$ ).

\begin{tabular}{|c|c|c|c|c|c|c|c|c|c|}
\hline \multirow{2}{*}{$\begin{array}{l}\text { Scheme } \\
\text { no. }\end{array}$} & \multicolumn{3}{|c|}{ Displacement } & \multirow{2}{*}{$\begin{array}{c}\text { Plastic } \\
\text { volume }\left(\mathrm{m}^{3}\right)\end{array}$} & \multicolumn{3}{|c|}{ Maximum forces } & \multicolumn{2}{|c|}{$\begin{array}{l}\text { Working status of support } \\
\text { members }\end{array}$} \\
\hline & $\begin{array}{l}\text { Roof } \\
(\mathrm{mm})\end{array}$ & $\begin{array}{l}\text { Side wall } \\
(\mathrm{mm})\end{array}$ & $\begin{array}{l}\text { Floor } \\
(\mathrm{mm})\end{array}$ & & $\begin{array}{l}\text { Arch axial } \\
\text { force }(\mathrm{kN})\end{array}$ & $\begin{array}{l}\text { Arch bending } \\
\text { moment }(\mathrm{kN})\end{array}$ & $\begin{array}{l}\text { Bolt axial } \\
\text { force }(\mathrm{kN})\end{array}$ & Arch & Rock bolt \\
\hline 6 & 78.0 & 125.1 & 71.5 & 88.1 & 1140.0 & 87.05 & 171.8 & Normal & Normal \\
\hline 7 & 77.0 & 127.7 & 94.9 & 60.8 & 1321.0 & 85.45 & 171.8 & Normal & Normal \\
\hline 8 & 107.2 & 155.0 & 136.2 & 72.1 & 824.4 & 73.77 & 171.8 & Failed & Normal \\
\hline 9 & 142.1 & 173.3 & 188.9 & 82.2 & 572.6 & 42.54 & 171.8 & Failed & Normal \\
\hline 10 & 189.9 & 213.6 & 252.8 & 91.4 & 443.4 & 66.46 & 171.8 & Failed & $\begin{array}{l}2 \text { bolts broken on the } \\
\text { side walls }\end{array}$ \\
\hline
\end{tabular}

increasing the allowable elongation of the free section of the bolt, and the specific physical and mechanical parameters of the energy-absorbing bolts are not considered. In Schemes 13-15, the arch locking bolts are used, and they are settled on the starting points of the semicircle at each side. The outside ends of the arch locking bolts are linked to the supporting arch, which are different to the conventional rock bolt, as the conventional one is independent to the arch. The length of locking bolt is $3.0 \mathrm{~m}$, the diameter is $22 \mathrm{~mm}$, and the other mechanical parameters are the same as the conventional one. The parameters of the U36 arch are listed in Table 3. In Schemes 13-15, there are arch locking bolts used on each leg of the arch, positioned $0.6 \mathrm{~m}$ downward from the starting point of the semicircle. The calculation of each scheme also terminated at the $50^{\text {th }}$ day, and some of the results are listed in Table 7.

\subsection{Results Analysis}

3.2.1. Comparing Analyses on Schemes 10-13 (Different Supports with the Same Ground Stress: $10 \mathrm{MPa}, \lambda=1.5)$. Figure 10 shows the plastic zones and support structure inner force diagrams of Schemes 10-13, and Figure 11 shows 

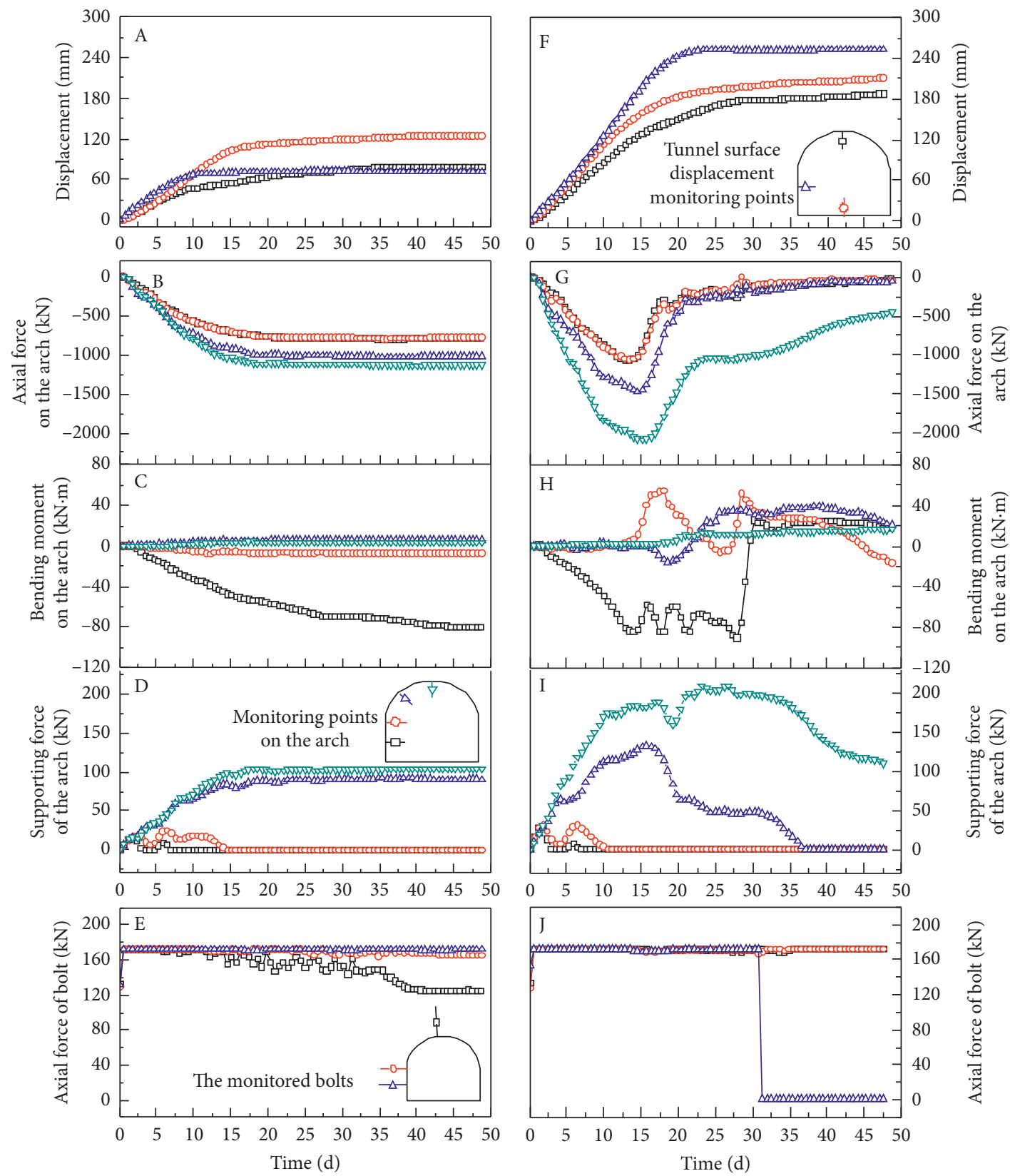

(a)

(b)

Figure 7: Evolution curves of (a) Scheme $6(\lambda=0.5)$ and (b) Scheme $10(\lambda=0.5)$. (A) (E): Evolution curves of roadway displacement, arch axial force, arch bending moment, arch supporting force, and rock bolt axial force of Scheme 6, respectively; (F) (J): Evolution curves of roadway displacement, arch axial force, arch bending moment, arch supporting force, and rock bolt axial force of Scheme 10, respectively.
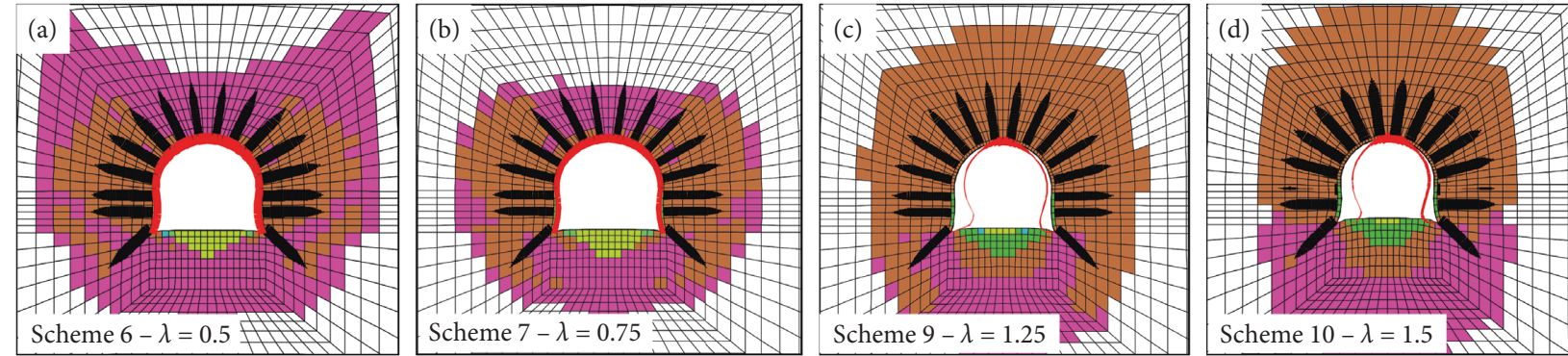

FiguRE 8: Surrounding rock plastic zones and supporting structure inner force diagrams of (a) Schemes 6, (b) Schemes 7, (c) Schemes 9, and (d) Schemes 10 at the $50^{\text {th }}$ day. 


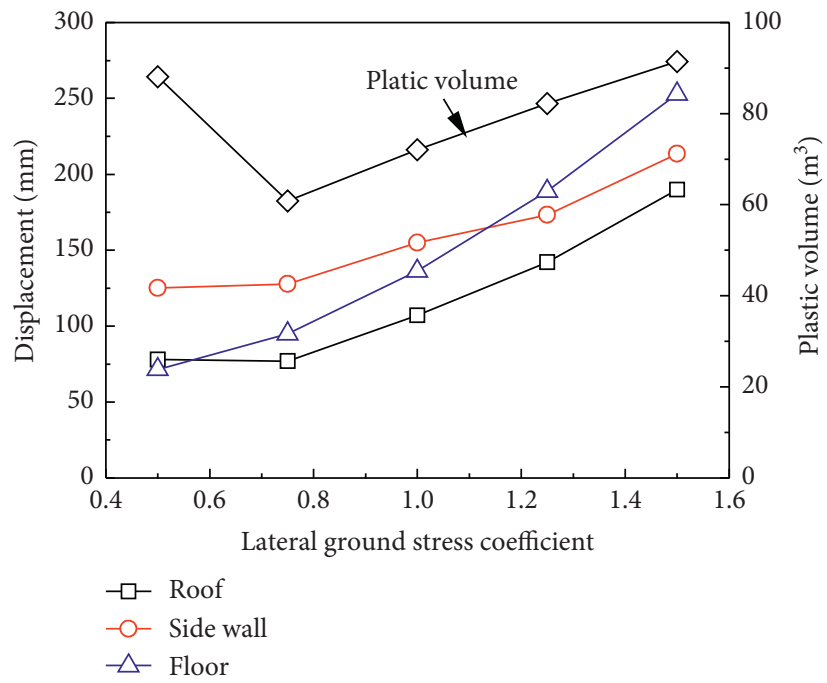

FIGURE 9: Variation curves of displacements and plastic zone volumes with lateral ground stress coefficient.

TABLE 6: The numerical schemes for enhanced support.

\begin{tabular}{lcccc}
\hline $\begin{array}{l}\text { Scheme } \\
\text { no. }\end{array}$ & Parameters of roadway & Support type and parameters & $\begin{array}{c}\text { Vertical ground stress } \\
(\mathrm{MPa})\end{array}$ & $\begin{array}{c}\text { Lateral ground stress } \\
\text { coefficient } \lambda\end{array}$ \\
\hline 11 & & CFST arch $+\Phi 22 \mathrm{~mm}$ bolts & 10 & 1.5 \\
12 & The same as Schemes & $\begin{array}{c}\text { CFST arch }+\Phi 18 \mathrm{~mm} \text { bolts }+ \text { energy- } \\
\text { absorbing bolts on the side walls }\end{array}$ & 10 & 1.5 \\
13 & $1 \sim 10$ & CFST arch $+\Phi 22 \mathrm{~mm}$ bolts + locking bolts & 10 & 1.5 \\
14 & & CFST arch $+\Phi 22 \mathrm{~mm}$ bolts + locking bolts & 15 & 1.0 \\
15 & & U36 arch $+\Phi 22 \mathrm{~mm}$ bolts + locking bolts & 10 & 1.5 \\
\hline
\end{tabular}

TABLe 7: Main results of Schemes $11-15$ at the $50^{\text {th }}$ day.

\begin{tabular}{|c|c|c|c|c|c|c|c|c|c|}
\hline \multirow{2}{*}{$\begin{array}{l}\text { Scheme } \\
\text { no. }\end{array}$} & \multicolumn{3}{|c|}{ Deformations } & \multirow{2}{*}{$\begin{array}{c}\text { Plastic } \\
\text { volume }\left(\mathrm{m}^{3}\right)\end{array}$} & \multicolumn{3}{|c|}{ Maximum forces } & \multicolumn{2}{|c|}{$\begin{array}{l}\text { Working status of } \\
\text { support members }\end{array}$} \\
\hline & $\begin{array}{l}\text { Roof } \\
(\mathrm{mm})\end{array}$ & $\begin{array}{l}\text { Side wall } \\
(\mathrm{mm})\end{array}$ & $\begin{array}{l}\text { Floor } \\
(\mathrm{mm})\end{array}$ & & $\begin{array}{l}\text { Arch axial } \\
\text { force }(\mathrm{kN})\end{array}$ & $\begin{array}{l}\text { Arch bending } \\
\text { moment }(\mathrm{kN})\end{array}$ & $\begin{array}{c}\text { Bolt axial force } \\
\qquad(\mathrm{kN})\end{array}$ & Arch & Bolt \\
\hline 11 & 168.2 & 172 & 247.5 & 84.8 & 640.2 & 66.5 & 260 & Normal & Normal \\
\hline 12 & 188.5 & 207.4 & 252.6 & 90.8 & 440.8 & 66.1 & 171.8 & Failed & Normal \\
\hline 13 & 125.2 & 132.0 & 238.6 & 75.1 & 2105 & 39.5 & 260 & Normal & Normal \\
\hline 14 & 270.0 & 399.1 & 337.9 & 111.6 & 345.5 & 91.4 & 260 & Failed & $\begin{array}{c}8 \text { bolts are } \\
\text { broken }\end{array}$ \\
\hline 15 & 182.4 & 179.0 & 253.2 & 91.4 & 1184 & 48.3 & 260 & Failed & Normal \\
\hline
\end{tabular}
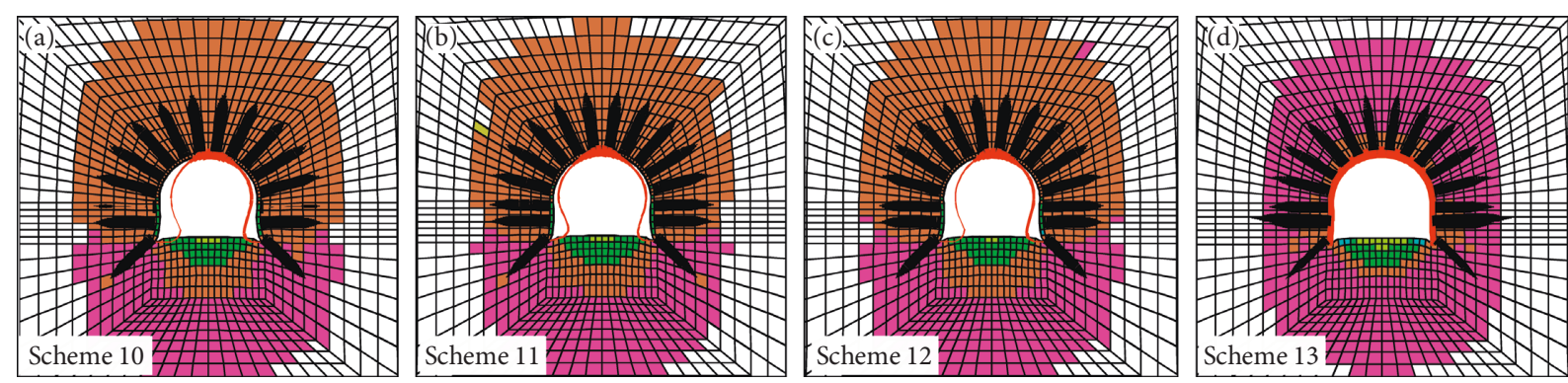

FIGURE 10: Surrounding rock plastic zones and supporting structure inner force diagrams of (a) Schemes 10, (b) Schemes 11, (c) Schemes 12, and (d) Schemes 13 at the $50^{\text {th }}$ day. 


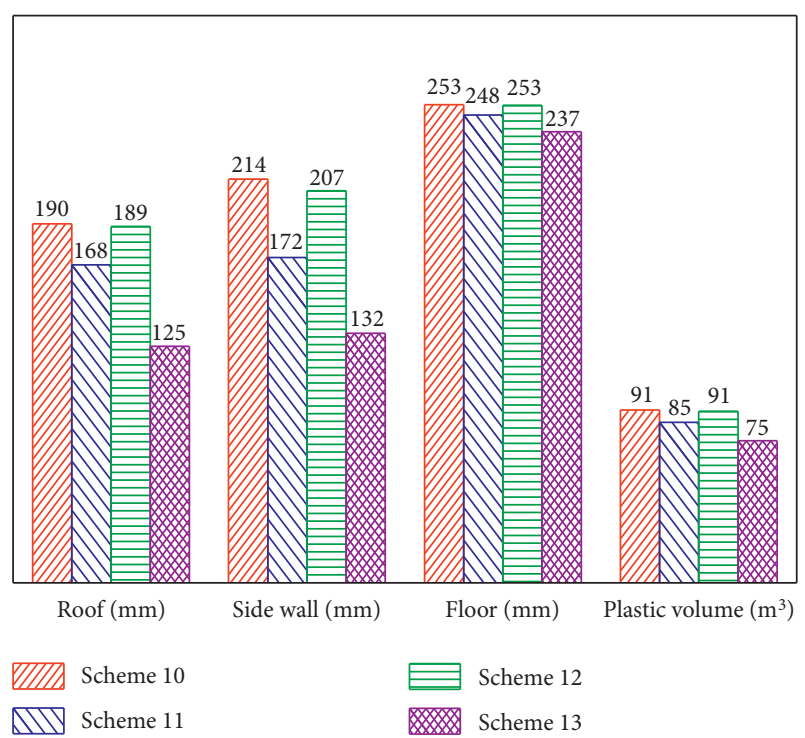

Figure 11: The comparative columns of roadway deformations and plastic zones of Schemes 10-13.

the comparative columns of surrounding rock control effects of Schemes 10-13.

(1) The only difference between Scheme 11 and Scheme 10 is that the $18-\mathrm{mm}$-diameter rock bolts were replaced with 22-mm-diameter bolts, which obviously enhanced the surrounding rock controlling effect. No bolts were broken in Scheme 11, and the side wall inward displacement was reduced by $20 \%$, but the arch still failed. The above results show that the highstrength bolts are necessary for soft rock roadways and explain why high-strength bolts are used widely today.

(2) The difference between Scheme 12 and Scheme 10 is that the conventional bolts on the side walls are replaced by energy-absorbing bolts. The comparison results show the obvious bolt protection effect of the energy-absorbing function, and the broken rock bolt problem was solved in this way. But the global control effect on the surrounding rocks was still weak.

(3) Schemes 11-12 show that the broken bolt problem can be effectively solved by enlarging the bolt diameter or by replacing the conventional bolt with an energyabsorbing bolt. But the above measures can do nothing to prevent the failure of the support arch, which is the key point of roadway support failure as analyzed in Section 2.3.2. Thus, these measures cannot significantly enhance the controlling effect of the surrounding rocks; they can just improve it slightly.

(4) Compared with all the other schemes, as shown in Figure 11, the controlling effect of the surrounding rock in Scheme 13 is the best; roof settlement and inward deformation of the side wall are the most convincing parameters, and the values are lower than those of Scheme 10 by $33.9 \%$ and $38 \%$, respectively. In addition, the broken bolt and supporting arch failure problems are both solved. Because there are only two more bolts in Scheme 13 than in Scheme 11, the cost of the increased support is low.

3.2.2. Stabilizing Mechanism of the Scheme Using Arch Locking Bolts (Scheme 13). Figure 12 shows the evolution curves of each index of Scheme 13. The following can be noted when comparing the analysis with Scheme 10 as shown in Figure 7(b).

(1) The axial forces on the arch in Scheme 10 show a risedown pattern, and the reduced axial forces happened first on the arch legs (Figures 7G, 13(d)) and then on the arch shoulders and crown. Due to the loss of axial forces, the supporting forces supplied by the arch also show a similar phenomenon. As shown in Figure 7I, the supporting forces on the arch legs decreased to 0 before the $10^{\text {th }}$ day, and the supporting forces on the shoulders and crown of the arch also decreased. The reason can be determined by combining with Figure 13(a) as follows: The arch legs were bent toward the excavation space slightly at the $10^{\text {th }}$ day, which led to separation of the surrounding rocks and arch legs. Although the bending deformations were not obvious, they led to the loss of supporting forces on the roadway walls. Then, the additional bending moments were generated due to the bending deformation of the arch legs (the inner forces on the half height of the legs approaches the compression-bending criterion very quickly as shown in Figure 7H), which caused the failure of the arch legs. After that, the bending deformation of the arch occurred rapidly, the arch lost its global structural mechanical property, and the arch failed overall.

(2) In Scheme 13, global failure of the arch did not occur (Figures 13(a) 13(d)), and the supporting forces remained at a high level until the end of the calculation. The deformation of the rock surrounding the roadway was well controlled because the deformation rate reduced to nearly 0 at the $20^{\text {th }}$ day. The controlling effects are more obvious on the side wall and roof of the roadway, compared with the results of Scheme 10. The axial force development curves of the arch in Scheme 13 (using locking bolts) are obviously different from that in Scheme 10. The curves show rise-stable pattern with no decreasing stage (Figure 12(a)). Similar pattern are shown by the supporting force curves as shown in Figure 12(c), except the one on the leg half height, which shows a short-term decline between the $3^{\text {rd }}$ and $18^{\text {th }}$ days. The working mechanism of arch locking bolts can be obtained through comparing Scheme 13 and Scheme 10. The locking bolts offered great restriction on the inner bending deformation of the arch legs, which limited the increase of the additional bending moment and prevented the strength failure of the section (the bending moments of the arch in Scheme 13 shown in Figure 12(b) are obviously lower than 


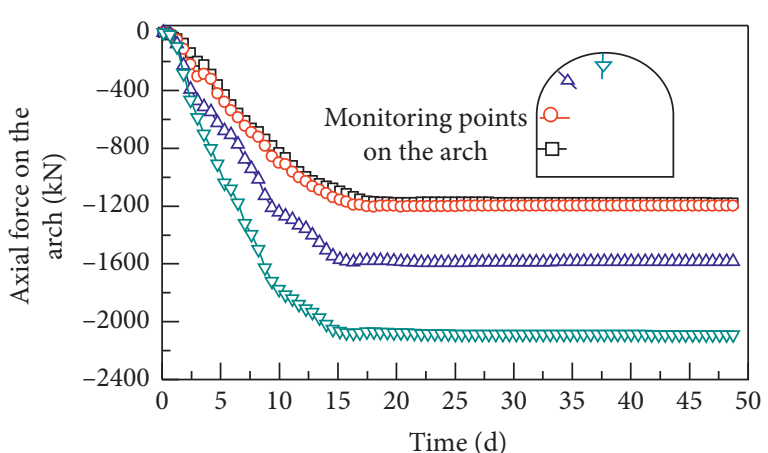

(a)

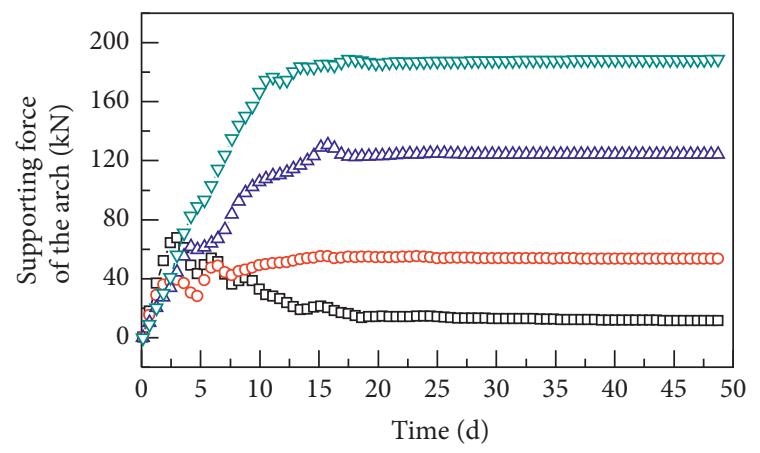

(c)

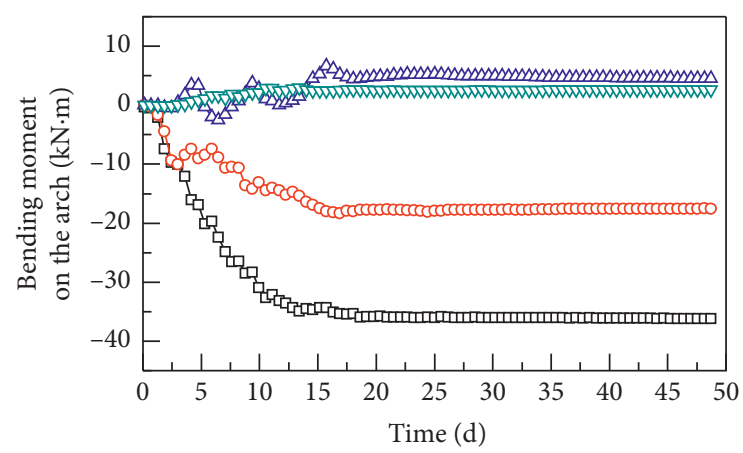

(b)

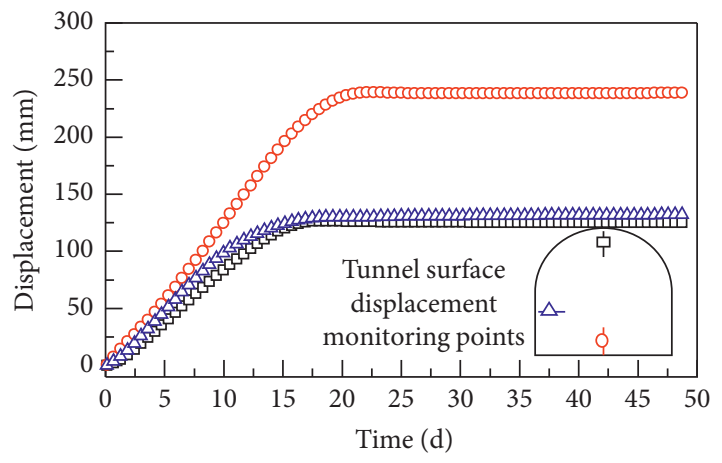

(d)

FIGURE 12: Evolution curves of (a) arch axial force, (b) arch bending moment, (c) arch supporting force, and (d) roadway displacement of Scheme 13.
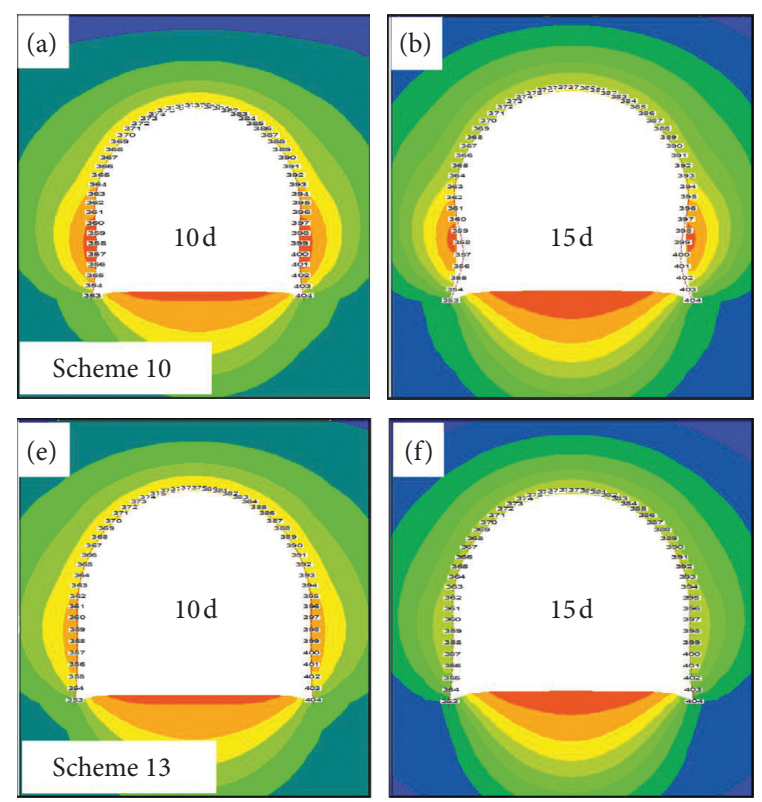
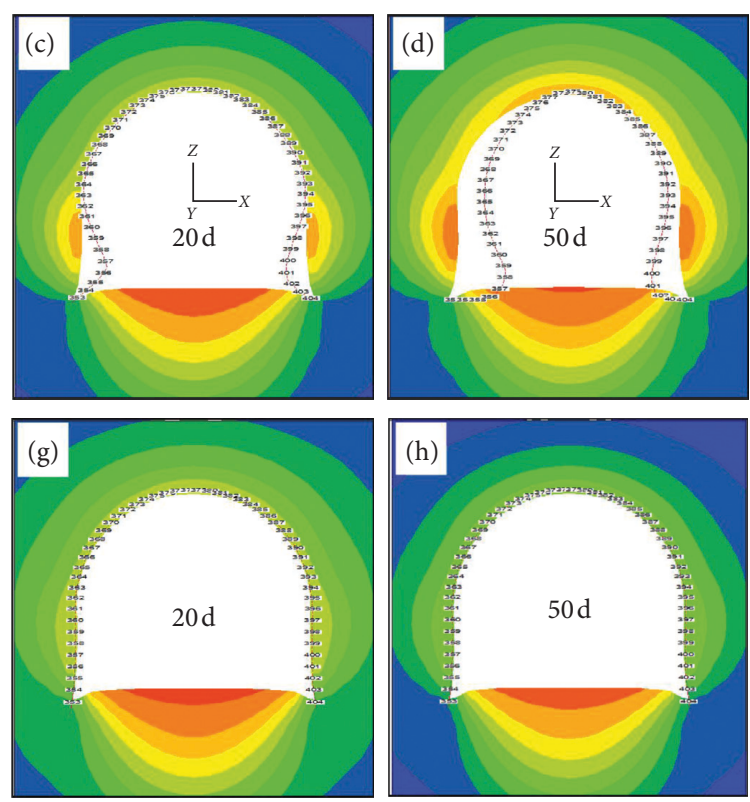

FIGURE 13: Deformations of the roadways and the supporting arches. (a)-(d): Scheme 10 at the $10^{\text {th }}$ day, $15^{\text {th }}$ day, $20^{\text {th }}$ day, and the $50^{\text {th }}$ day; (e)-(h): Scheme 13 at the $10^{\text {th }}$ day, $15^{\text {th }}$ day, $20^{\text {th }}$ day, and the $50^{\text {th }}$ day.

those in Scheme 10). The arch maintained good arch shape, which is a great benefit to fully exploit the supporting ability of the arch. Roof settling was also controlled due to the well-maintained integrity of the arch structure.
3.2.3. Analysis of the Scheme Using Arch Locking Bolts in a Higher Ground Stress Condition (Scheme 14, Ground Stress $15 \mathrm{MPa}$, Comparing with Scheme 4). Figures 14(a) and 14(b) show the evolution curves of axial forces and supporting forces of the arch. Figure 14(c) shows the plastic 


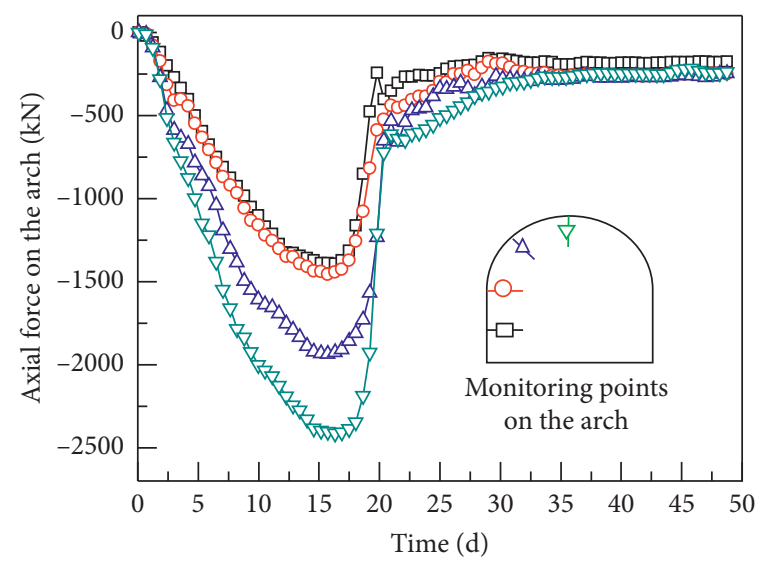

(a)

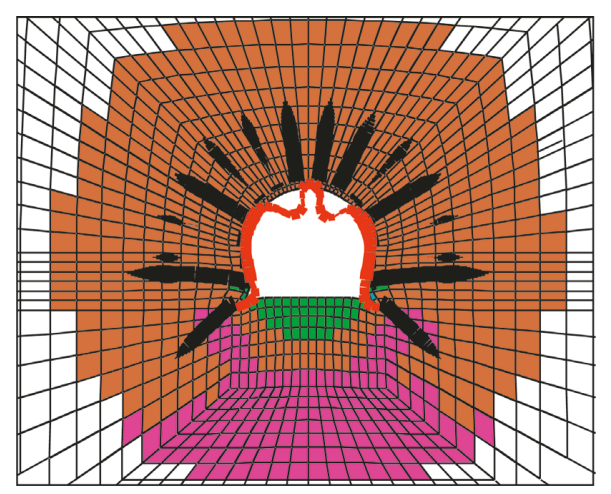

(c)

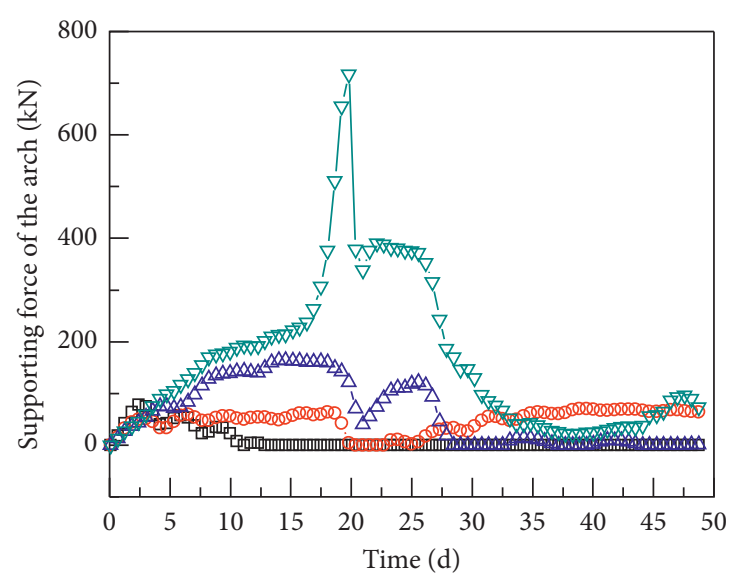

(b)

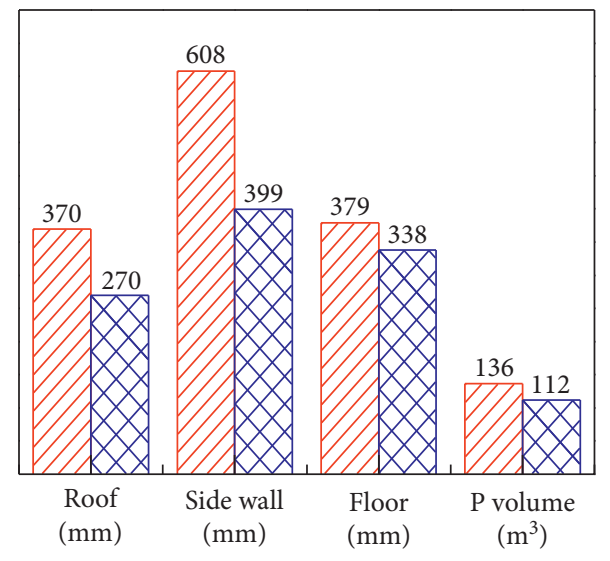

ZIII Scheme 4

$\square$ Scheme 14

(d)

Figure 14: Main results of Scheme 14. (a) Arch axial force curves. (b) arch supporting forces. (c) Surrounding rock plastic zones and supporting structure inner force diagrams. (d) Comparative columns of the surrounding rock control effect of Scheme 14 and Scheme 4.

zone of the surrounding rocks and support structure inner force diagrams of Schemes 14 at the $50^{\text {th }}$ day. Figure $14(\mathrm{~d})$ shows the surrounding rock controlling effect columns compared with Scheme 4 (conventional supports with the same condition).

(1) Because the locking bolts were used, the arch leg bending deformations, as shown in Figure 14(c), were much smaller than that in Scheme 4. The broken bolt problem was relieved but not solved (Figure 14(c)). The surrounding rock deformation and the plastic zone were significantly smaller than those in Scheme 4, especially the side wall displacement.

(2) As shown in Figure 14(c), the locking bolt shows an obvious control effect on the bending deformation of the arch leg. Because the surrounding rock pressure was too high, the arch crown became a new breakthrough which surrounding rock pressure was released, and the arch crown deformed seriously. Finally, the arch failed globally, the axial forces and supporting forces of the arch decreased to a very low level (Figures 14(a) and 14(b)). This is a very interesting phenomenon that the failure position of supporting arch changed as the ground stress rose. It tell us that some of the surrounding rock energy has to be released, especially in the deep ground; it is not a good way to stop the deformation of the surrounding rock blindly.

(3) A comprehensive comparison of Schemes 11-13 shows that for the soft rock roadway in a lower ground stress condition, the supporting structure and parameter optimization can be adopted as a functional tool for controlling the stability of the surrounding rock. For a higher ground stress condition, a semicircular roadway with two straight walls has obvious limitations compared with the curved wall shape, horseshoe shape, three-centered shape, and circular shape. In some conditions, it is very difficult to control the stability of the roadway only through optimization of the support structures and parameters. Cross-sectional shape optimization 


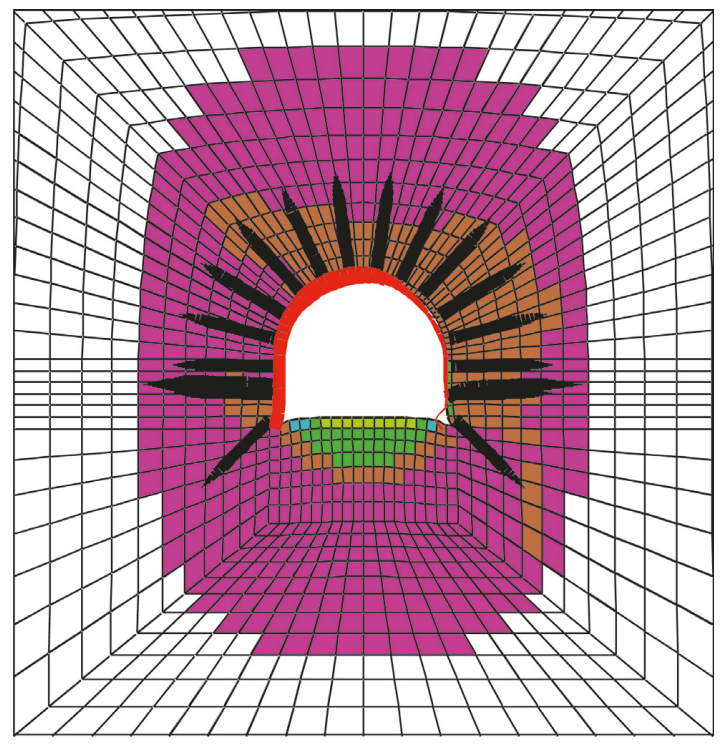

(a)

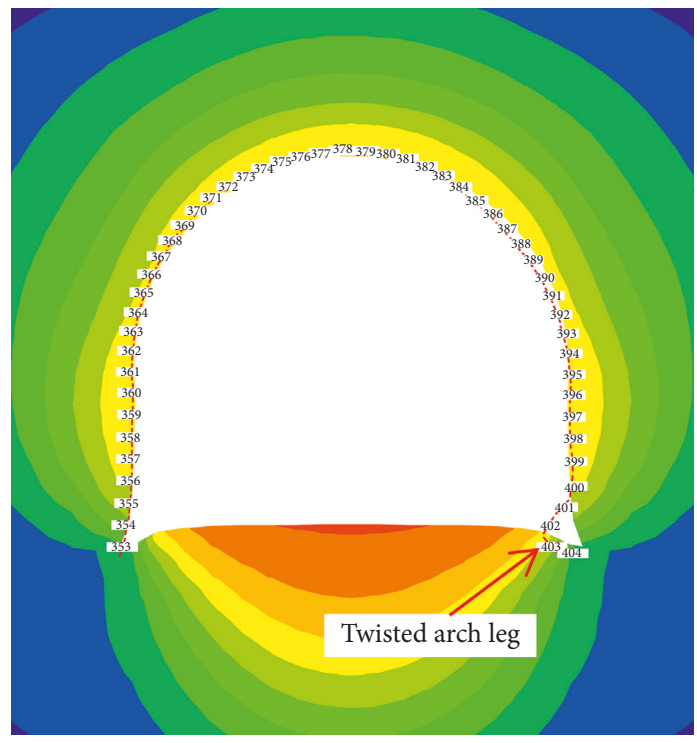

(b)

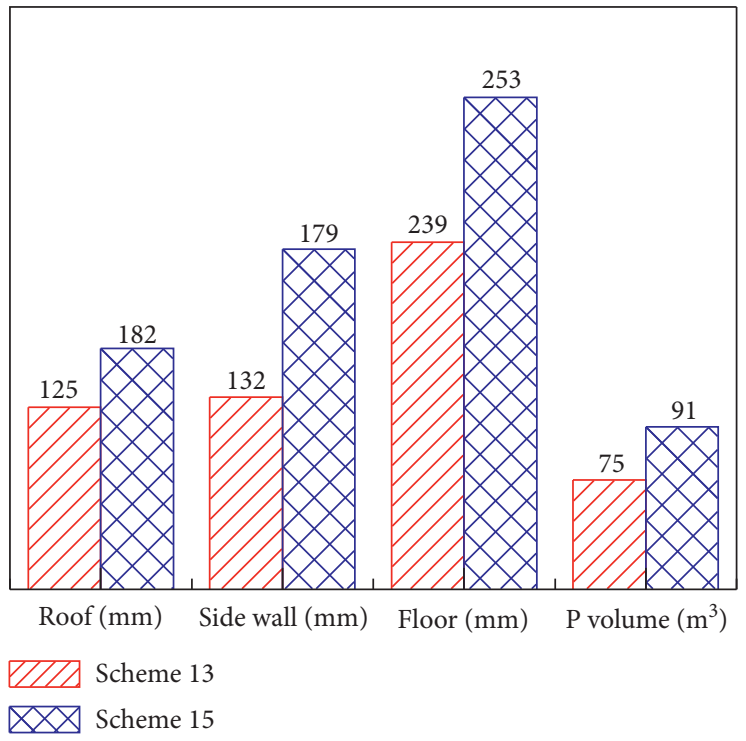

(c)

Figure 15: Main results of Scheme 15. (a) Surrounding rock plastic zone and supporting structure inner force diagrams. (b) Roadway displacement contour at the $50^{\text {th }}$ day. (c) Comparative columns of surrounding rock control effects of Scheme 13 and Scheme 15.

should be taken as an important option for roadway support design in high-ground stress conditions.

\subsubsection{Comparing Analysis of the U-Steel Arch and CFST Arch} (Scheme 15 and Scheme 13). Figures 15(a) and 15(b) show the plastic zone and displacement contour of the surrounding rocks, and the support structure inner force and deformation diagrams. Figure 15(c) shows the controlling effect of the surrounding rock in Scheme 15 compared with Scheme 13.

(1) Although locking bolts were used, the U36 steel arch still experienced bending failure (on the lower position in the right leg of the arch). The results indicate that for the supporting structure design in roadway support, even if the potential supporting failure is concerned, the strength of the supporting component still needs serious consideration.

(2) Figure 15(c) shows that there was less roadway deformation of the CFST arch scheme than there was with the U-steel arch scheme, which means that the support strength of the CFST arch was significantly improved compared with the U36 steel arch, which has similar steel volume as the CFST arch $(150 \mathrm{~mm} \times 8 \mathrm{~mm})$. The CFST arch has much higher applicability in a roadway that has higher surrounding rock pressure or is buried in soft rock ground layers. 


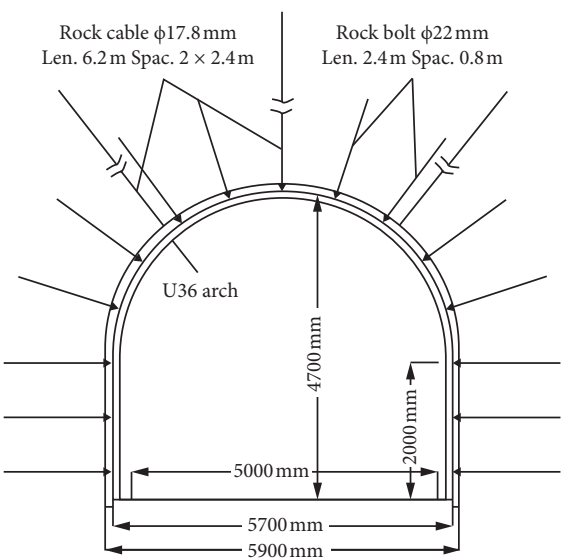

(a)

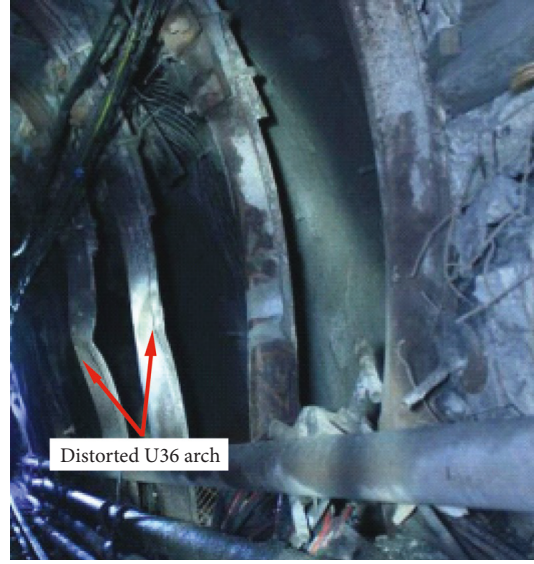

(b)

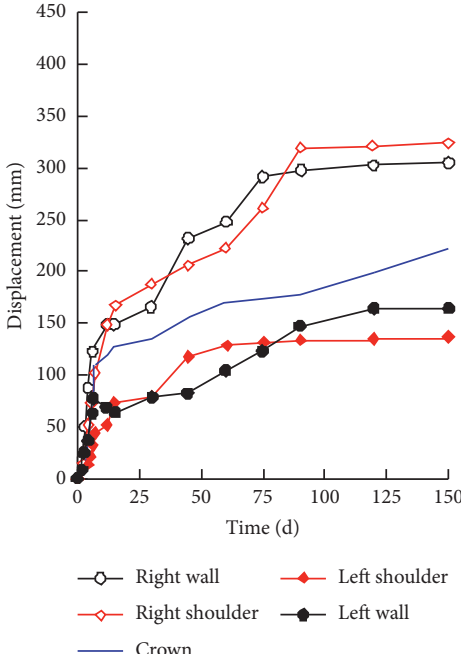

(c)

FIgURE 16: The original support scheme and effect. (a) Original support scheme with U36 steel arch. (b) Distorted U36 arch. (c) Monitoring curves of the roadway under the original scheme.
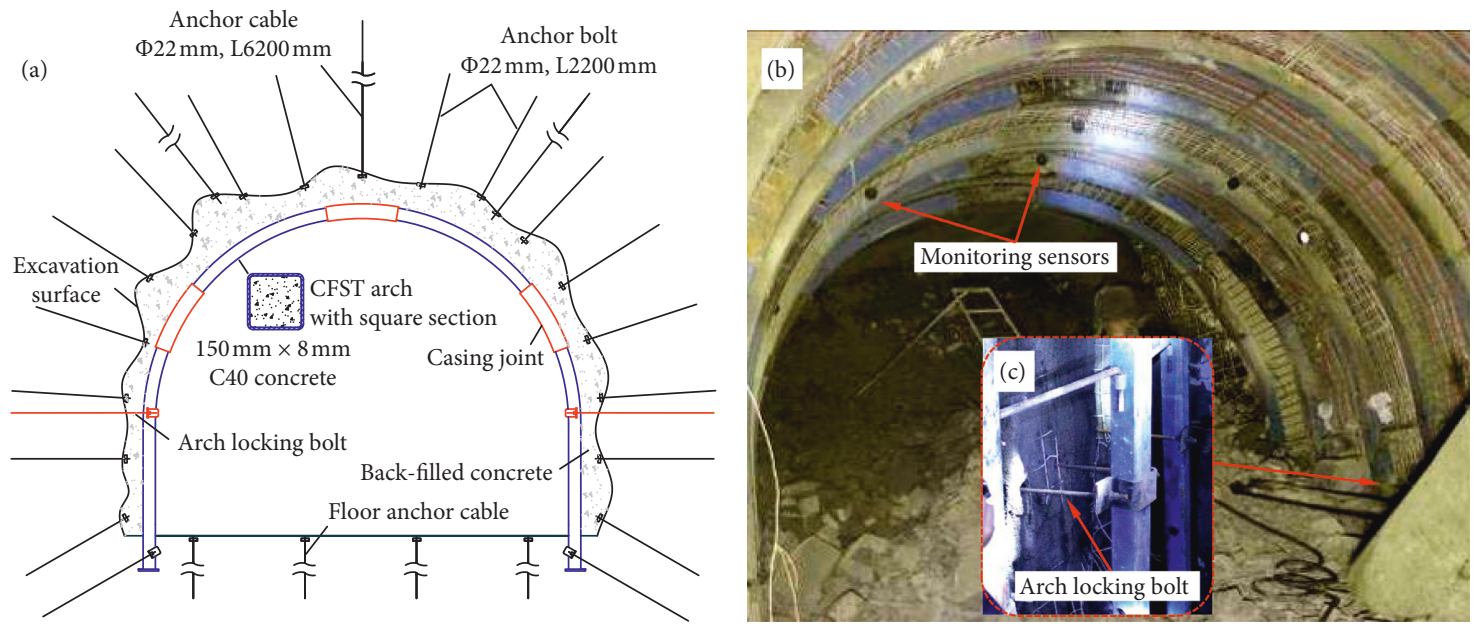

FIGURE 17: Field test of CFST arch-bolt composite scheme with arch locking bolts. (a) Supporting scheme with CFST arches and arch locking bolts. (b) Overall picture of the roadway during construction. (c) Arch locking bolt.

\section{Practice Study}

4.1. Situations of the Roadway Using the Original Support. Zhaolou coal mine is located in the middle of Juye Coal area in east China, and the designed production capacity is 3.0 Mt/a. The second downhill roadway of the Zhaolou coal mine is buried more than $1000 \mathrm{~m}$ deep, and its service period is 60 years. There are remarkable geological structures in this area, and the practice area passes through the fault DF7, where the development of vertical tension fractures was significant. The lithology is changeable and mainly consists of mudstone, shale, and coal. The rock quality is poor, and the roadway stability is difficult to control.

The initial support scheme of the roadway was rock bolt + steel mesh + shotcrete. But obvious deformation appeared in the roadway, part of shotcrete layer cracked and peeled off, and the initial support scheme failed to maintain roadway stability. In view of this problem, the U36 steel arches were used as the strengthened support (Figure 16(a)). The row spacing of U36 arches was $1.0 \mathrm{~m}$. However, the deformation of the roadway still cannot be well controlled by the strengthened U-steel arch support. The monitoring results show that the U36 arches were distorted (Figure 16(b)), the roof settlement reached $218 \mathrm{~mm}$, the deformation of the arch shoulder reached $322 \mathrm{~mm}$, and the roadway was still deforming at the $150^{\text {th }}$ day (Figure 16(c)). The deformations of the roadway seriously affected the use of the roadway.

4.2. Effects of the New Support Scheme. Based on the conclusions in Sections 2 and 3 of the article, the U-steel arches were replaced by the CFST arch in the test scheme as shown in Figure 17(a). The parameters of the rock bolts, steel mesh, and shotcrete layer are the same as in the original scheme. 

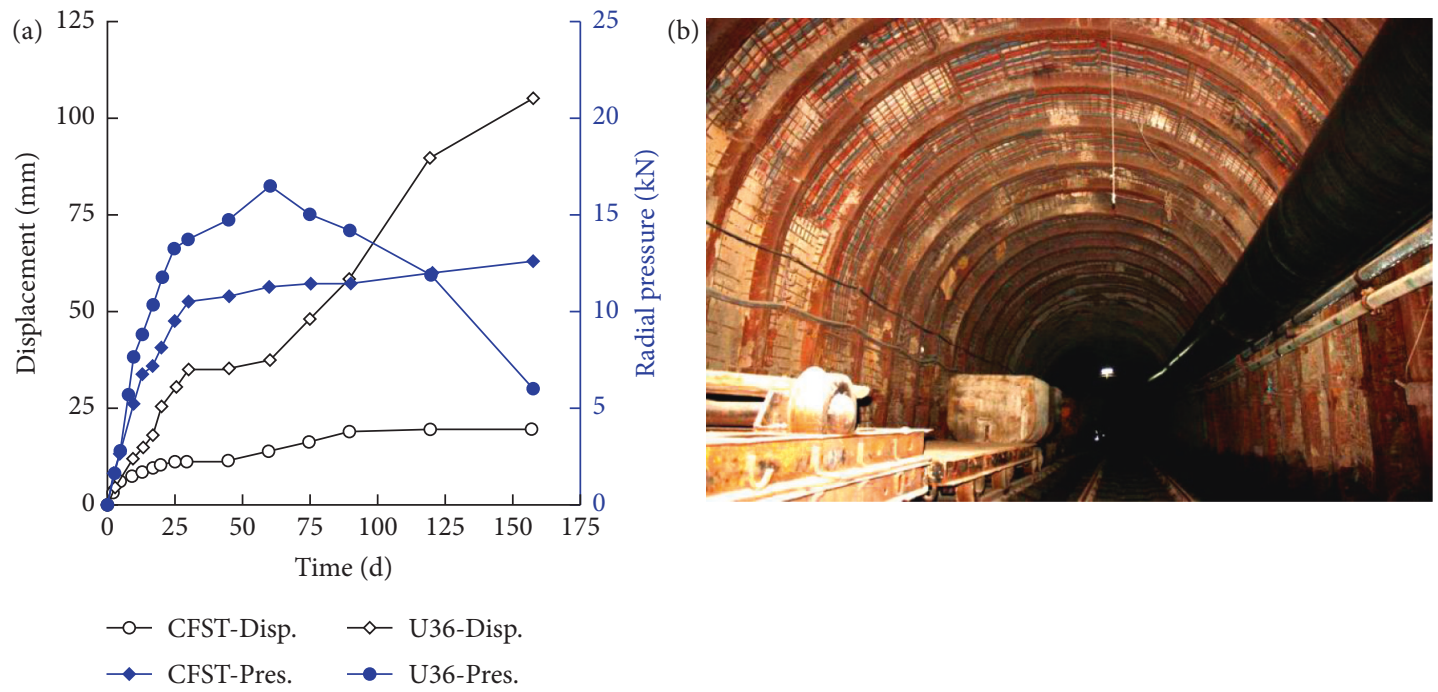

FIGURE 18: Effects of field test of CFST arch-bolt composite scheme with arch locking bolts. (a) Monitoring curves. (b) Overall picture of the roadway 1.5 years later.

Anchor cables $(\Phi 22 \mathrm{~mm} \times L 6200 \mathrm{~mm})$ were added on the roadway floor; the spacing and row spacing are $1500 \mathrm{~mm}$ and $1600 \mathrm{~mm}$, respectively. The cross section of the CFST arch is square, the width of the steel tube is $150 \mathrm{~mm}$, the thickness is $8 \mathrm{~mm}$, and the filled concrete grade is C40. The length of the casing joint is $900 \mathrm{~mm}$, and the width and thickness of the casing tube are $180 \mathrm{~mm}$ and $12 \mathrm{~mm}$, respectively. The row spacing of the arch is $1 \mathrm{~m}$, the width of the arch is $5 \mathrm{~m}$, the height is $4.3 \mathrm{~m}$, and the height of the arch legs is $1.8 \mathrm{~m}$. Because the arch legs may bend and fail, the locking bolts are installed near the starting point of the arch as shown in Figure 16(c). The diameter of the locking bolt is $22 \mathrm{~mm}$ and the length is $3 \mathrm{~m}$ (Figures $17(\mathrm{~b})$ and $17(\mathrm{c})$ ). To equalize the pressure on the arch, the space between the arch and the rocks was filled with concrete grade C20. The monitoring devices and sensors were installed during the construction process (Figure 17(b)).

Figure 18(a) shows the monitoring results of the new support scheme and the original U36 arch support scheme. The average value of radial pressure of CFST arch at $157 \mathrm{~d}$ was $12.57 \mathrm{kN}$, and the value of U36 arch was $10.14 \mathrm{kN}$. The average deformation of CFST arch support roadway was $15.7 \mathrm{~mm}$, only $28 \%$ of that of U36 arch support roadway. In addition, the roadway under the control of U36 arch support system was not stable, and the deformation was still continuing and yield failure appeared on some U36 arch. However, the yield failure problem did not appear on the CFST arches because their support strength is higher than the U36 arch. The stress monitoring of the back-filling concrete shows that the stress of the back-filling concrete was far lower than the compressive strength of C20 concrete, which effectively guarantees the safety of the support system. Figure 17(b) shows the roadway 1.5 years after excavation and support. Field test results show that the CFST arch and rock bolt composite support scheme with arch locking bolts provide much higher controlling capacity than the original scheme.

\section{Conclusions}

(1) The failure mechanism of the arch-bolt composite supported roadway in a semicircular roadway with two straight walls is discussed. First, side wall rocks deforming inward in the roadway space in the early stage leads to the compression-bending failure of the arch legs and finally induced the global instability of the supporting arch. Second, the arch legs separated from the side wall in the earlier stage caused the loss of the controlling effect on the side walls rocks and the global deformation and failure of the roadway. Third, the rock bolts breakage promoted the deformation and failure process. The side walls of the roadway and the legs of the supporting arch are the key points of failure in a semicircular roadway with two straight walls.

(2) The controlling measures research shows the following: (a) the bolt broken problem can be solved by enlarging the bolt diameter or replacing the bolts with energy-absorbing bolts, but control of the surrounding rock can hardly be enhanced. (b) The locking bolts can significantly restrict the bending deformation of the arch legs, which limited the increase of the additional bending moment, prevented strength failure, and preserved good arch shape so that the arch structure could be fully exploited. (c) In deep or soft rock roadways, the semicircular roadway shape with two straight walls has obvious limitation. It is difficult to control the stability of the roadway solely through optimization of the support structure and parameters. (d) The strength parameters of the supporting structure (especially the arch) are still the most important part of the design, and the CFST arch is more suitable for a roadway with higher ground stress compared with the U-steel arch. 
(3) The field test of the CFST arch-bolt composite support scheme with arch locking bolts was carried out in a 1000-m-deep roadway in Zhaolou coal mine, and the results indicate that the conclusions drawn in this article are reliable.

\section{Data Availability}

The data used to support the findings of this study are included within the article.

\section{Conflicts of Interest}

The authors declare that they have no conflicts of interest.

\section{Acknowledgments}

The work was supported by the National Natural Science Foundation of China (grant nos. 51604166 and 41772299), the Natural Science Foundation of Jiangsu Higher Education Institutions (grant no. 17KJB440002); the Qingdao Postdoctoral Research Project, China (grant no. 2016130), the Open Fund of Jiangsu Collaborative Innovation Center for Building Energy Saving and Construct Technology, China (grant no. SJXTBS1701), and the Research and Innovation Team Project of College of Civil Engineering and Architecture, Shandong University of Science and Technology, China (grant no. 2019TJKYTD02).

\section{References}

[1] M. He, W. Gong, J. Wang et al., "Development of a novel energy-absorbing bolt with extraordinarily large elongation and constant resistance," International Journal of Rock Mechanics and Mining Sciences, vol. 67, pp. 29-42, 2014.

[2] H. Kang, "Support technologies for deep and complex roadways in underground coal mines: a review," International Journal of Coal Science \& Technology, vol. 1, no. 3, pp. 261-277, 2014.

[3] B. H. G. Brady and E. T. Brown, Rock Mechanics for Underground Mining, Kluwer Academic Publishers, Dordrecht, Netherlands, 3rd edition, 2004.

[4] K. Skrzypkowski, "A new design of support for burst-prone rock mass in underground ore mining," E3S Web of Conferences, vol. 71, Article ID 00006, 2018.

[5] L. N. Y. Wong, Q. Fang, and D. Zhang, "Mechanical analysis of circular tunnels supported by steel sets embedded in primary linings," Tunnelling and Underground Space Technology, vol. 37, no. 6, pp. 80-88, 2013.

[6] X. Chang, X. Luo, C. Zhu, and C. Tang, "Analysis of circular concrete-filled steel tube (CFT) support in high ground stress conditions," Tunnelling and Underground Space Technology, vol. 43, pp. 41-48, 2014.

[7] W. T. Li, N. Yang, Y. C. Mei et al., "Experimental investigation of the compression-bending property of the casing joints in a concrete filled steel tubular supporting arch for tunnel engineering," Tunnelling and Underground Space Technology, vol. 96, 2020.

[8] Q. Wang, B. Jiang, S. C. Li et al., "Experimental studies on the mechanical properties and deformation \& failure mechanism of U-type confined concrete arch centering," Tunnelling and Underground Space Technology, vol. 51, pp. 20-29, 2016.
[9] W. Zhang, W. Li, N. Yang, Q. Wang, T. Li, and G. Wang, "Determination of the bearing capacity of a concrete-filled steel tubular arch support for tunnel engineering: experimental and theoretical studies," KSCE Journal of Civil Engineering, vol. 21, no. 7, pp. 2932-2945, 2017.

[10] A. Bobet, "Elastic solution for deep tunnels. Application to excavation damage zone and rockbolt support," Rock Mechanics and Rock Engineering, vol. 42, no. 2, pp. 147-174, 2009.

[11] K. Skrzypkowski, W. Korzeniowski, K. Zagórski, and A. Zagórska, "Flexibility and load-bearing capacity of roof bolting as functions of mounting depth and hole diameter," Energies, vol. 12, no. 19, p. 3754, 2019.

[12] G. Wang, W. Han, Y. Jiang, H. Luan, and K. Wang, "Coupling analysis for rock mass supported with CMC or CFC rockbolts based on viscoelastic method," Rock Mechanics and Rock Engineering, vol. 52, no. 11, pp. 4565-4588, 2019.

[13] J. H. Chen, S. L. Yang, and H. B. Zhao, "The analytical approach to evaluate the load-displacement relationship of rock bolts," Advances in Civil Engineering, vol. 2019, Article ID 2678905, 15 pages, 2019.

[14] C. Carranza-Torres and M. Diederichs, "Mechanical analysis of circular liners with particular reference to composite supports. for example, liners consisting of shotcrete and steel sets," Tunnelling and Underground Space Technology, vol. 24, no. 5, pp. 506-532, 2009.

[15] R. Rodríguez and M. B. Díaz-Aguado, "Deduction and use of an analytical expression for the characteristic curve of a support based on yielding steel ribs," Tunnelling and Underground Space Technology, vol. 33, no. 33, pp. 159-170, 2013.

[16] G. Gunter and R. G. Gschwandtner, "Input to the application of the convergence confinement method with time-dependent material behaviour of the support," Tunnelling and Underground Space Technology, vol. 12, no. 2, pp. 13-22, 2012.

[17] B. Gong, Y. Jiang, K. Okatsu, X. Wu, J. Teduka, and K. Aoki, "The seepage control of the tunnel excavated in high-pressure water condition using multiple times grouting method," Processes, vol. 6, no. 9, p. 159, 2018.

[18] Z. Qin, X. Chen, and H. Fu, "Damage features of altered rock subjected to drying-wetting cycles," Advances in Civil Engineering, vol. 2018, no. 5, pp. 1-10, 2018.

[19] P.-P. Sun, X.-X. Yang, D.-K. Sun, W.-G. Qiao, and Y. Wu, "Geometric and mechanical properties of a shear-formed fracture occurring in a rock bridge between discontinuous joints," Bulletin of Engineering Geology and the Environment, pp. 1-16, 2019.

[20] H. M. Wu, Y. M. Shu, and J. G. Zhu, "Implementation and verification of interface constitutive model in FLAC3D," Water Science and Engineering, vol. 4, no. 3, pp. 305-316, 2011.

[21] W. Liu, Q. Feng, C. Wang, C. Lu, Z. Xu, and W. Li, "Analytical solution for three-dimensional radial heat transfer in a coldregion tunnel," Cold Regions Science and Technology, vol. 164, no. 164, Article ID 102787, 2019.

[22] W. Li, N. Yang, B. Yang et al., "An improved numerical simulation approach for arch-bolt supported tunnels with large deformation," Tunnelling and Underground Space Technology, vol. 77, pp. 1-12, 2018.

[23] W. P. Huang, Q. Yuan, Y. L. Tan et al., "An innovative support technology employing a concrete-filled steel tubular structure for a 1000-m-deep roadway in a high in situ stress field," Tunnelling and Underground Space Technology, vol. 73, pp. 26-36, 2018.

[24] W. T. Li, N. Yang, T. C. Li et al., "Implementation of bolt broken failure in FLAC3D and its application," Chinese Journal of Rock Mechanics and Engineering, vol. 35, no. 4, pp. 753-767, 2016, in Chinese. 


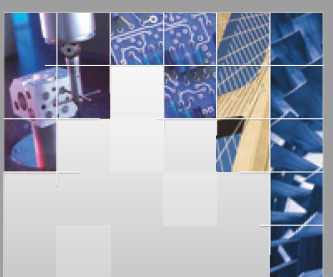

\section{Enfincering}
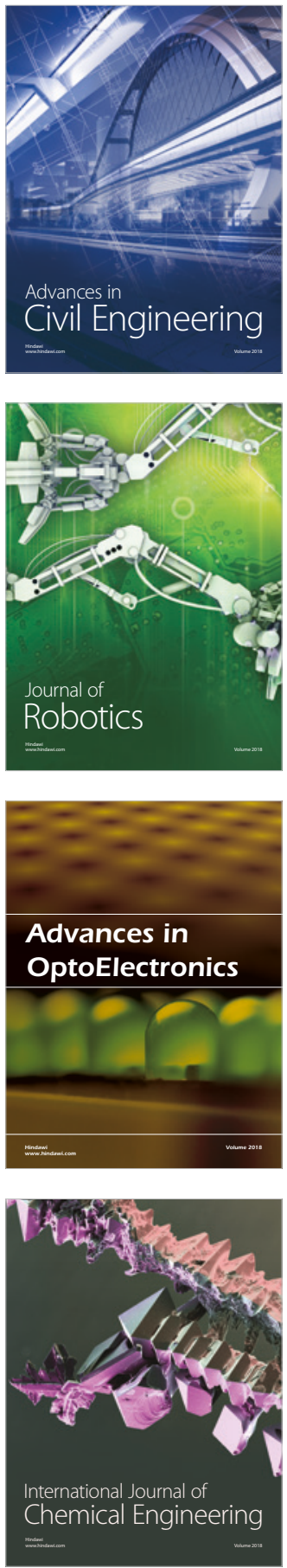

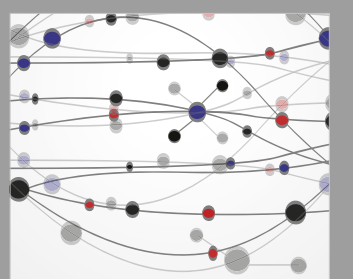

\section{Rotating \\ Machinery}

The Scientific World Journal

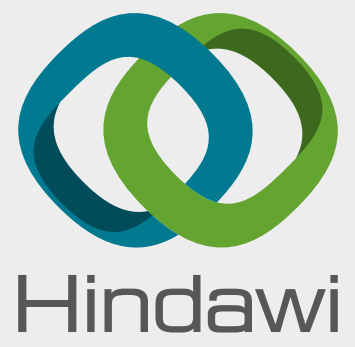

Submit your manuscripts at

www.hindawi.com
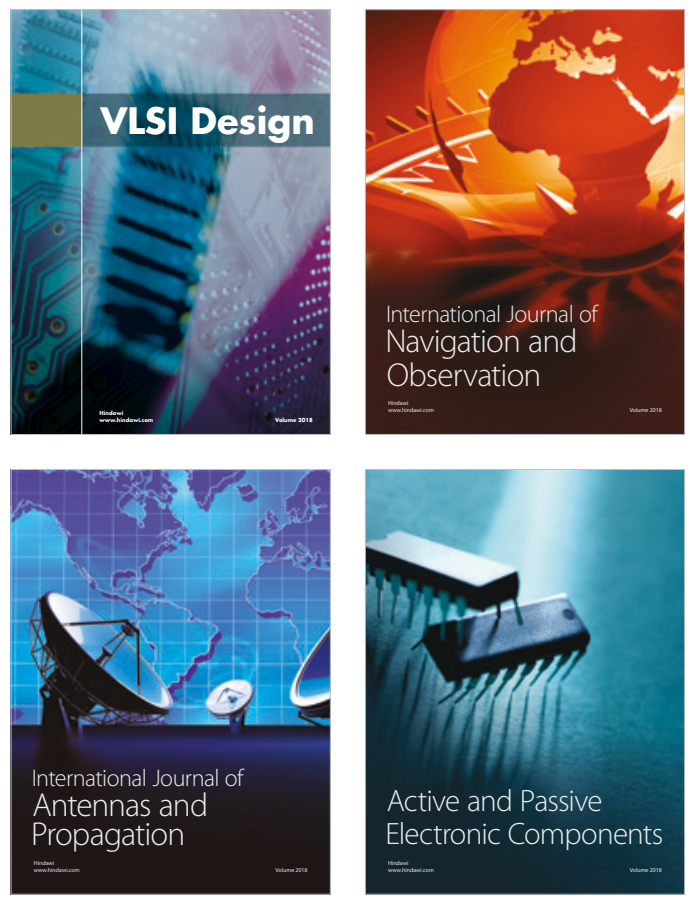
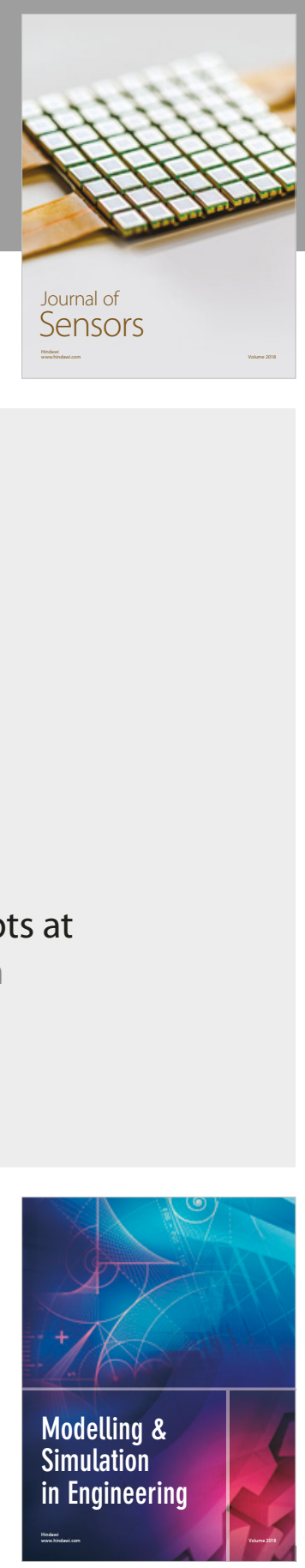

\section{Advances \\ Multimedia}
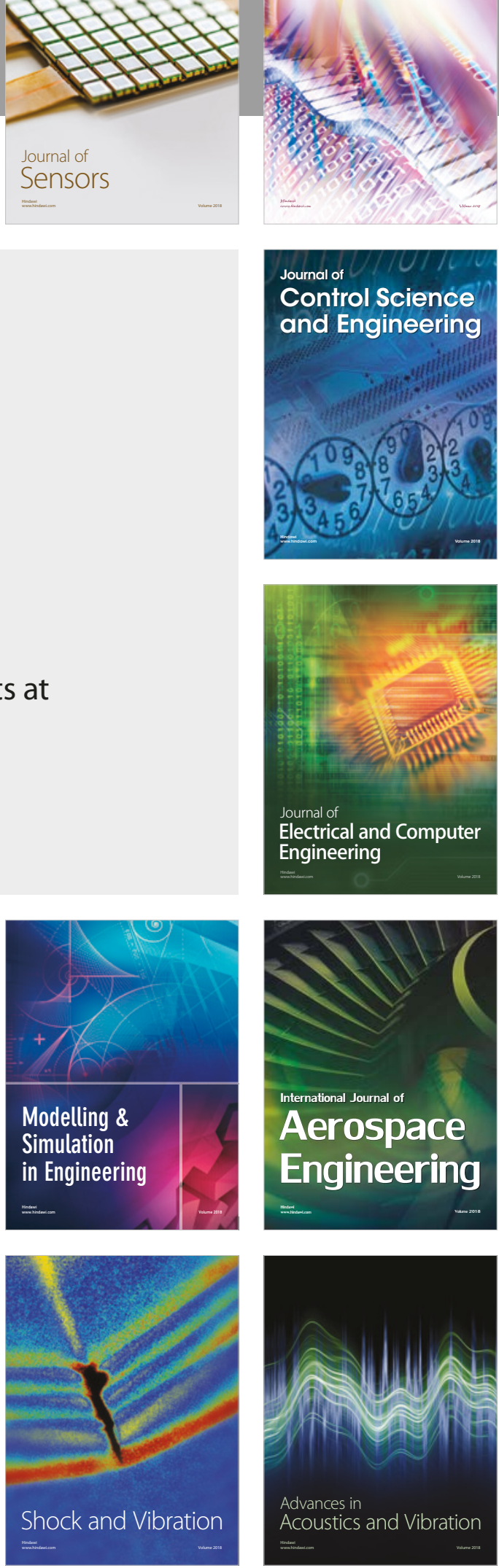